\title{
The Tendaguru Formation (Late Jurassic to Early Cretaceous, southern Tanzania): definition, palaeoenvironments, and sequence stratigraphy
}

\author{
Robert Bussert ${ }^{1}$, Wolf-Dieter Heinrich ${ }^{2}$ and Martin Aberhan*,2 \\ ${ }^{1}$ Institut für Angewandte Geowissenschaften, Technische Universität Berlin, Skr. BH 2, Ernst-Reuter-Platz 1, 10587 Berlin, Germany. \\ E-mail: robert.bussert@tu-berlin.de \\ ${ }^{2}$ Museum für Naturkunde - Leibniz Institute for Research on Evolution and Biodiversity at the Humboldt University Berlin, Invalidenstr. 43, \\ 10115 Berlin, Germany. E-mail: wolf-dieter.heinrich@mfn-berlin.de; martin.aberhan@mfn-berlin.de
}

Received 8 December 2008 Accepted 15 February 2009 Published 3 August 2009

\begin{abstract}
The well-known Late Jurassic to Early Cretaceous Tendaguru Beds of southern Tanzania have yielded fossil plant remains, invertebrates and vertebrates, notably dinosaurs, of exceptional scientific importance. Based on data of the German-Tanzanian Tendaguru Expedition 2000 and previous studies, and in accordance with the international stratigraphic guide, we raise the Tendaguru Beds to formational rank and recognise six members (from bottom to top): Lower Dinosaur Member, Nerinella Member, Middle Dinosaur Member, Indotrigonia africana Member, Upper Dinosaur Member, and Rutitrigonia bornhardti-schwarzi Member. We characterise and discuss each member in detail in terms of derivation of name, definition of a type section, distribution, thickness, lithofacies, boundaries, palaeontology, and age. The age of the whole formation apparently ranges at least from the middle Oxfordian to the Valanginian through Hauterivian or possibly Aptian. The Tendaguru Formation constitutes a cyclic sedimentary succession, consisting of three marginal marine, sandstone-dominated depositional units and three predominantly coastal to tidal plain, fine-grained depositional units with dinosaur remains. It represents four third-order sequences, which are composed of transgressive and highstand systems tracts. Sequence boundaries are represented by transgressive ravinement surfaces and maximum flooding surfaces. In a more simple way, the depositional sequences can be subdivided into transgressive and regressive sequences/systems tracts. Whereas the transgressive systems tracts are mainly represented by shallow marine shoreface, tidal channel and sand bar sandstones, the regressive systems tracts predominantly consist of shallow tidal channel, tidal flat, and marginal lagoonal to supratidal deposits.
\end{abstract}

\author{
Mesozoic \\ Gondwana \\ lithofacies \\ lithostratigraphy \\ biostratigraphy
}

1909; Krenkel 1911; Hennig 1914a, 1937a; Janensch 1914a; Staff 1914; Parkinson 1930a; Quennell et al. 1956; Aitken 1961; Kent et al. 1971; Mpanda 1997).

The Tendaguru area first received worldwide notice in scientific circles through the efforts of the famous German Tendaguru Expedition of 1909 to 1913 (GTE) that is regarded as one of the largest and most significant palaeontological expeditions ever to have taken place (Hennig 1912a; Janensch 1912, 1914b; Maier 2003). The GTE focused primarily on the recovery of dinosaur bones, but field work also concentrated on the

\footnotetext{
* Corresponding author
} 
surface geology, geomorphology, and the collection of invertebrate fossils. A series of monographs on the geology (e.g. Hennig 1914a), geomorphology (Staff 1914), invertebrates (e.g. Dietrich 1914, 1933a; Lange 1914; Zwierzycki 1914), and vertebrates, notably dinosaurs (e.g. Hennig 1925; Janensch 1929a, 1935, 1955, 1961a), published by the members of the GTE and their collaborators still remains the basis for the work of geologists and palaeontologists in the Tendaguru region. One of the main scientific results obtained was a detailed account of the sequence of Mesozoic and Cenozoic strata exposed in the hinterland of Lindi and Kilwa (Hennig 1914a; Janensch 1914a). Based on extended geological and palaeontological observations the "Tendaguruschichten" (= Tendaguru Beds) were established by Hennig (1914a) and Janensch (1914a) to define a sequence of Late Jurassic to Early Cretaceous strata which contain dinosaur remains of exceptional scientific interest that continue to play a key role in palaeontological research.

The GTE was followed by the British Tendaguru Expedition (BTE) from 1924 through 1931 that likewise concentrated on the recovery of dinosaur bones but also continued the study of the Tendaguru Beds (Migeod 1927, 1930, 1931; Parkinson 1930a, 1930b). Important geological research was undertaken by W. G. Aitken in the 1950s. His extensive exploration of the Mesozoic rocks in the Mandawa-Mahokondo and Makangaga (south)-Ruawa regions (Aitken 1954, 1956a, 1956b, 1957, 1958; Quennell et al. 1956) resulted in a fundamental summary account of the geology and palaeontology of the Jurassic and Cretaceous deposits of southern Tanzania (Aitken 1961) that significantly contributed to the knowledge of the Tendaguru Beds.

Great progress towards a more detailed understanding of the Tendaguru Beds has been made by the German-Tanzanian Tendaguru Expedition (GTTE) that conducted geological and palaeontological field work in the surroundings of Tendaguru Hill in September 2000 (Heinrich et al. 2001; Aberhan et al. 2002; Maier 2003). The exploration resulted in a standard section for the Tendaguru Beds (R. Bussert in Heinrich et al. 2001 and Aberhan et al. 2002). New fossil material, notably microfossils, sedimentological and stratigraphical data were collected that have substantially extended our knowledge of the Mesozoic strata in the Tendaguru area (e.g. Aberhan et al. 2002; Arratia et al. 2002; Bussert \& Aberhan 2004; Schrank 2005; Süss \& Schultka 2006; Msaky 2007; Sames 2005, 2008) and provided, together with previously published records, a sufficient base for a reappraisal of the Tendaguru Beds.

Nevertheless, there have been gaps in our understanding of the Tendaguru Beds. The data obtained by the GTTE have shown that the term "Tendaguruschichten", which was widely used in the literature for about hundred years, is not in accordance with the guidelines of the International Commission on Stratigraphy (Murphy \& Salvador 1999), as previously suggested by Schudack (1999). Moreover, the link of eustatic sea lev- el changes to the various sedimentary divisions of the Tendaguru Beds has scarcely received the attention it merits. The present study reviews the available evidence and attempts to remedy some of these deficiencies.

Here we provide a reinterpretation of the Tendaguru Beds. Our principal goals are (1) to describe the Tendaguru Beds and to raise them to the rank of a formation; (2) to describe the lithostratigraphic subdivisions of the Tendaguru Beds and to elevate them to the rank of members; (3) to characterise the depositional environments of the formation in its type area; and (4) to provide a sequence stratigraphic interpretation of the Tendaguru Formation.

The present paper is dedicated to the German Tendaguru Expedition that celebrates its centenary in 2009.

\section{Previous work}

The first report of the geology and palaeontology of the Tendaguru area, which is named after Tendaguru Hill located approximately $10 \mathrm{~km}$ south of Mtapaia in the Lindi district, southeast Tanzania (Fig. 1), was made by the German geographer Wilhelm Bornhardt who explored much of the hinterland of Lindi and Kilwa in 1896 and 1897 (Bornhardt 1900). He collected fossils at several sites such as Ntandi located approximately $15 \mathrm{~km}$ southeast of Tendaguru Hill and dated them as Neocomian (Müller 1900; Weissermel 1900). It is worth noting that as early as 1897 , Bornhardt collected a bone fragment of a supposed dinosaur in a stream section near Nambango village, situated about $15 \mathrm{~km}$ southeast of Tendaguru Hill. The poorly preserved specimen was first tentatively identified as a plesiosaur (Müller 1900; Hennig 1914a). Bornhardt never visited Tendaguru Hill, and erroneously mapped it as a small gneiss monadnock in the early stage of research (Bornhardt 1900: geological map VI).

The first palaeontologist to explore the Jurassic and Cretaceous rocks exposed in the surroundings of Tendaguru Hill was Eberhard Fraas in 1907 (Wild 1991). He concentrated on the recovery of dinosaur bones, but also collected fossil invertebrates, e.g. from Ntandi, Tendaguru Hill, Matapua, Niongala, and Mikadi, which were regarded as Early Cretaceous (Krenkel 1910). Niongala, though, was tentatively assigned to the Cenomanian by Fraas (1908). Along with a description of the dinosaur remains, he gave an account of the stratigraphy of the Mesozoic deposits exposed in the Tendaguru area and assigned the whole succession to the Cretaceous, including his Late Cretaceous dinosaurbearing bed that was described as light-coloured, sandy marl with intercalated friable, coarse-grained sandstone (Fraas 1908).

During the field work of the GTE, interest in the geology and palaeontology of the Tendaguru area received a new impetus. Large-scale excavations were successfully undertaken to recover dinosaur bones that 


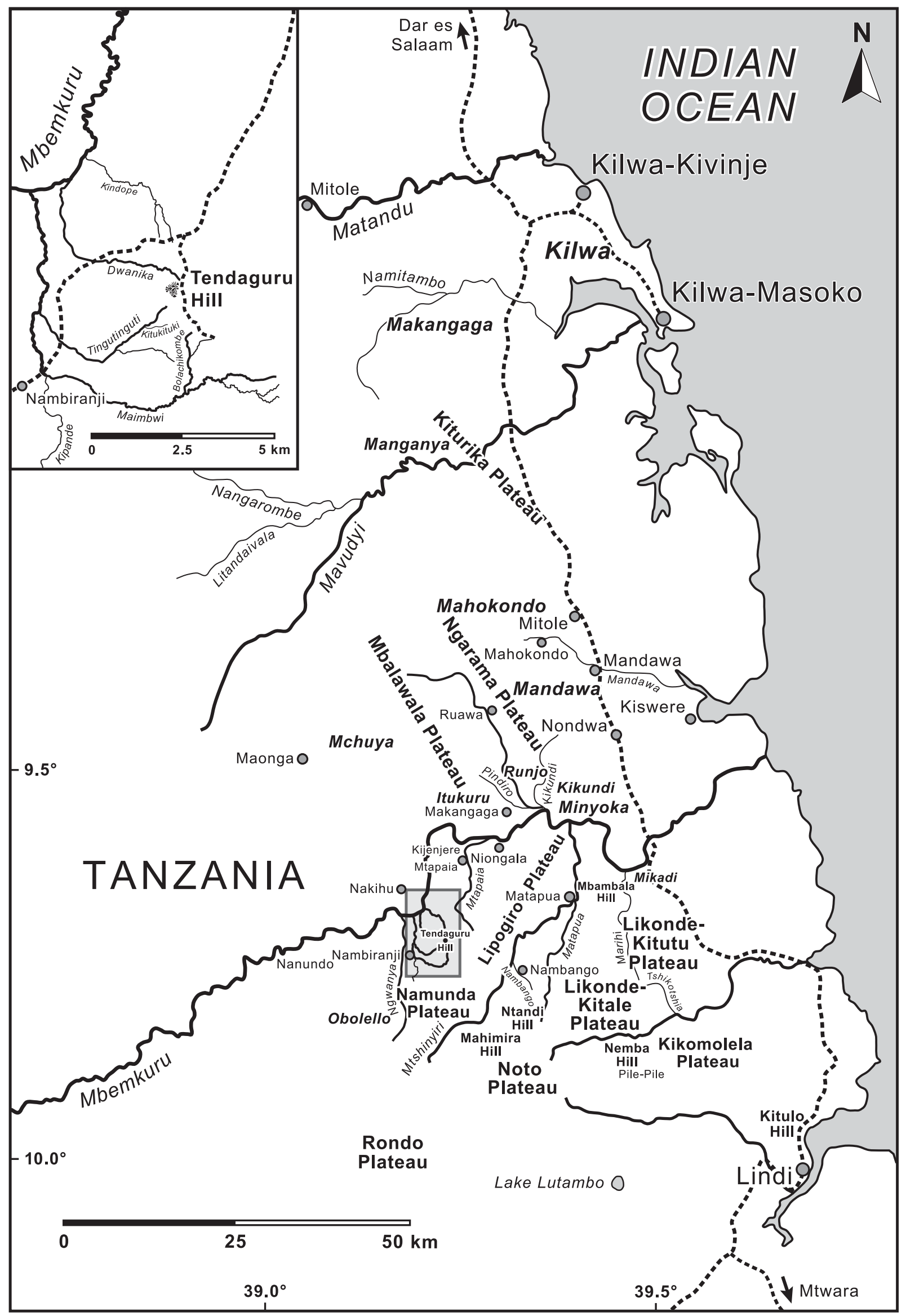

Figure 1. Geographic map of the coastal region of southern Tanzania, East Africa, indicating localities and geographic features mentioned in the text. Insert shows geographic details of the type area of the Tendaguru Formation. 
Table 1. Stratigraphic terms for the Tendaguru Formation as used in previous studies.

\begin{tabular}{|c|c|c|}
\hline Proposed name & Previous names & Literature \\
\hline \multirow{10}{*}{ 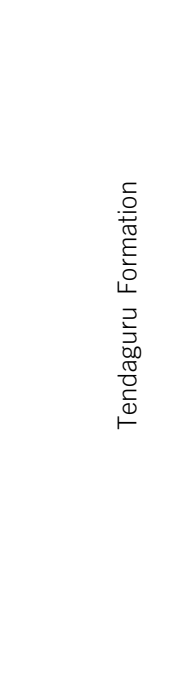 } & Tendaguru-Schichten & $\begin{array}{l}\text { Hennig (1912c, 1924, 1927, 1937a); Zwierzycki (1914); Krenkel } \\
\text { (1925, 1957); Kapilima (1984); Heinrich (2003) }\end{array}$ \\
\hline & Tendaguru-Serie & Hennig (1912, 1937b); Hölder (1964) \\
\hline & Tendaguruschichten & $\begin{array}{l}\text { Hennig (1914a); Janensch (1914c); Janensch \& Hennig (1914); } \\
\text { Dietrich (1914, 1933a, 1933b); Lange (1914); Sames (2005) }\end{array}$ \\
\hline & Tendaguru Series & $\begin{array}{l}\text { Schuchert (1918); Spath (1928-1933); Parkinson (1930b); Wade } \\
\text { (1937); Aitken (1956b, 1961); Cox (1965); Zils et al. (1995); Mpanda (1997) }\end{array}$ \\
\hline & Gigantosaurus Beds & Gregory (1921) \\
\hline & Tendaguru Beds & $\begin{array}{l}\text { Simpson (1926); Teale (1934); Haughton (1938); Arkell (1956); Quennell et al. } \\
\text { (1956); Heinrich (1999a); Bonaparte et al. (2000); Heinrich et al. (2001); Aberhan } \\
\text { et al. (2002); Bussert \& Aberhan (2004); Schrank (2004, 2005); Remes (2007) }\end{array}$ \\
\hline & Tendaguru reptile beds & Furon (1963) \\
\hline & Tendaguru Formation & $\begin{array}{l}\text { Raath \& Maclntosh (1987); Schudack (1999); Schudack \& Schudack (2002); } \\
\text { Süss \& Schultka (2006); Msaky (2007) }\end{array}$ \\
\hline & Tendaguru Group & Schlüter (1997) \\
\hline & Tendaguru formation & Sames (2008) \\
\hline
\end{tabular}

chiefly occurred in three discrete horizons (Janensch 1914b; Maier 2003), the uppermost of which is, in fact, equivalent to the dinosaur horizon described by Fraas (1908). In addition, fossil invertebrates and plants were collected. The dinosaur-bearing Tendaguru Beds (Hennig 1914a; Janensch 1914a; Table 1) are well exposed in the immediate surroundings of Tendaguru Hill such as in the Tingutinguti, Maimbwi, and Dwanika stream sections. These exposures are of exceptional interest as they allow a subdivison of the Tendaguru Beds and the observation of the vertical distribution of the fauna and flora they contain, especially the dinosaur assemblages.

Lithological and palaeontological studies of the succession formed the basis for the subdivision of the Tendaguru Beds into six units, all of them representing discrete depositional settings (Janensch 1914a) (Table 2). Most subsequent workers used this subdivision that still holds. However, different opinions have also been advanced regarding the succession and age of strata at Tendaguru Hill (e.g. Kitchin 1929; Parkinson 1929, 1930a; Spath 1928-1933). Parkinson (1929, 1930b), for instance, erroneously doubted the existence of the Lower Saurian Bed and considered the Middle and Upper Saurian Bed as one stratum of continental deposits that interrupted the continuous deposition of marine sediments in the former Tendaguru area. Moreover, Parkinson $(1929,1930 b)$ considered the Nerinea Bed as a lower and local interval of the Trigonia smeei Bed.

Dietrich (1933a, 1933b) subdivided the Nerinea Bed into two units, with the Sandstone with Trigonia dietrichi at the base and the Littoral with Cyrena and Mytilus at the top. Gregory (1921) used the term Gigantosaurus Beds for the dinosaur-bearing deposits at Tendaguru Hill. In addition, Gregory (1921), followed by Parkinson (1930b) and Wade (1937), applied the names
Upper, Middle, and Lower Reptile Bed for the dinosaur-bearing deposits of the Tendaguru Beds.

The three dinosaur-bearing beds were described as sandy, partly greenish-grey, partly reddish marl; the remaining three units as sandstone-dominated deposits containing marine invertebrate assemblages (Janensch 1914a; Behrend 1918). In the immediate surroundings of Tendaguru Hill, the thickness of the Tendaguru Beds was estimated at approximately $125 \mathrm{~m}$ (Janensch 1914a).

Hennig (1914a) suggested that the dinosaur-bearing beds are linked by brackish transitional beds to the intercalated marine strata. Dietrich (1933a) described these transitional strata as littoral deposits with 'Cyrena' [=Eomiodon $]$ and 'Mytilus' [=Falcimytilus $]$ among others. The nomenclature of some eponymous macroinvertebrates has changed since that time. Therefore, some workers applied the terms Rutitrigonia schwarzi Bed instead of Trigonia schwarzi Bed and Indotrigonia africana Bed instead of Trigonia smeei Bed (e.g. Raath \& McIntosh 1987), following the taxonomical revisions by Aitken (1961).

Bedding planes within the succession are broadly parallel. Therefore, the whole succession of sediments was originally regarded as a continuous, fairly flat-lying and undisturbed series of strata (Hennig 1914a, 1937a; Janensch 1914a). Later, an unconformity that coincides with a considerable break in the faunal succession between the Upper Saurian Bed and the Trigonia schwarzi Bed was recognised (Schuchert 1918, 1934; Parkinson 1930b; Dietrich 1933a, 1933b; Spath 1928-1933; Quennell et al. 1956; Aitken 1961). Moreover, an unconformity located at the top of the Nerinea Bed was also taken into consideration (Schuchert 1918).

Interpretation of the depositional environments of the Tendaguru Beds has differed considerably. Janensch (1914a) regarded the three dinosaur-bearing deposits as 
Table 2. Stratigraphic terms for the subdivisions of the Tendaguru Formation as used in previous studies and the new nomenclature as defined in this study.

\begin{tabular}{|c|c|c|c|}
\hline \multicolumn{2}{|c|}{ Proposed names } & Previous names & Literature \\
\hline \multirow{36}{*}{ 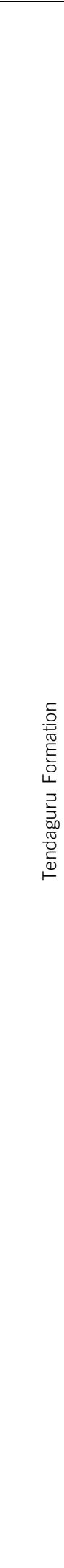 } & \multirow{22}{*}{$\begin{array}{l}\text { Rutitrigonia } \\
\text { bornhardti- } \\
\text { schwarzi } \\
\text { Member }\end{array}$} & $\begin{array}{l}\text { Trigonia-bornhardti und schwarzi- } \\
\text { Schicht }\end{array}$ & Hennig (1914a) \\
\hline & & Trigonia schwarzi-Schichten & $\begin{array}{l}\text { Dietrich (1914, 1927a); Heinrich (2003); Sames } \\
\text { (2005) }\end{array}$ \\
\hline & & Trigonia schwarzi-Schicht & $\begin{array}{l}\text { Lange (1914); Zwierzycki (1914); Behrend (1918); Dietrich } \\
\text { (1926) }\end{array}$ \\
\hline & & Schwarzi-Schicht & $\begin{array}{l}\text { Dietrich (1914, 1925b); Hennig (1914c); } \\
\text { Janensch \& Hennig (1914) }\end{array}$ \\
\hline & & $\begin{array}{l}\text { Obere Sandsteinzone mit } \\
\text { Trigonia schwarzi }\end{array}$ & Janensch (1914a) \\
\hline & & Trigonia schwarzi zone & Lull (1915); Simpson (1926) \\
\hline & & Trigonia-schwarzi-Horizont & Behrend (1918) \\
\hline & & $\begin{array}{l}\text { Upper sandstones with } \\
\text { Trigonia schwarzi }\end{array}$ & Schuchert (1918) \\
\hline & & Schwarzi-Stufe & Hennig (1924); Dietrich (1933a, 1933b) \\
\hline & & Trigonia schwarzi Beds & Parkinson (1930b); Wade (1937); Haughton (1938) \\
\hline & & Trigonia schwarzi Bed & $\begin{array}{l}\text { Parkinson (1930b); Aitken (1956b, 1961); Quennell } \\
\text { et al. (1956); Heinrich (1999a); Bonaparte et al. (2000); } \\
\text { Heinrich et al. (2001); Aberhan (2002); Schrank } \\
\text { (2004, 2005); Msaky (2007) }\end{array}$ \\
\hline & & Schwarzi Beds & Teale (1934) \\
\hline & & Schwarzi-Bornhardti-Zone & Hennig (1937a) \\
\hline & & Bornhardti-Schwarzi-Zone & Hennig (1937b); Krenkel (1957) \\
\hline & & Trigonia schwarzi Sandstone & Arkell (1956) \\
\hline & & $\begin{array}{l}\text { Marine transgressive beds with Trigonia } \\
\text { schwarzi and Hoplites neocomiensis }\end{array}$ & Furon (1963) \\
\hline & & Schichten mit Trigonia schwarzi & Hölder (1964) \\
\hline & & Rutitrigonia schwarzi Bed & Raath \& McIntosh (1987) \\
\hline & & Bornhardti-Schwarzi Complex & Zils et al. (1995) \\
\hline & & Trigonia Schwarzi Member & Schlüter (1997) \\
\hline & & Trigonia Schwarzi member & Sames (2008) \\
\hline & & Schwarzi Member & Schudack (1999); Schudack \& Schudack (2002) \\
\hline & \multirow{14}{*}{$\begin{array}{l}\text { Upper Dinosaur } \\
\text { Member }\end{array}$} & Dinosaurierhorizont & Fraas (1908) \\
\hline & & Oberster Saurier-Horizont & Hennig (1914a); Zwierzycki (1914); Behrend (1918) \\
\hline & & Oberste (dritte) Saurierzone & Janensch (1914c) \\
\hline & & Obere Sauriermergel & Janensch (1914c); Krenkel (1957) \\
\hline & & Obere Saurierschicht & Dietrich (1914); Hennig (1914b, 1914c) \\
\hline & & Upper dinosaur horizon & Lull (1915) \\
\hline & & Upper or third dinosaur zone & Schuchert (1918). \\
\hline & & Upper Reptile Bed & Gregory (1921); Parkinson (1930b); Wade (1937) \\
\hline & & Obere Saurier-Schicht & Hennig (1924, 1937a, 1937b); Dietrich (1927a) \\
\hline & & Oberer Saurier-Horizont & Krenkel (1925) \\
\hline & & Upper dinosaur beds & Simpson (1926) \\
\hline & & Upper Dinosaur Bed & Parkinson (1930b); Msaky (2007) \\
\hline & & Oberer Sauriermergel & Dietrich (1933a, 1933b) \\
\hline & & Upper Saurian Horizon & Teale (1934) \\
\hline
\end{tabular}


Table 2. continued

\begin{tabular}{|c|c|c|c|}
\hline \multicolumn{2}{|c|}{ Proposed names } & Previous names & Literature \\
\hline \multirow{36}{*}{ 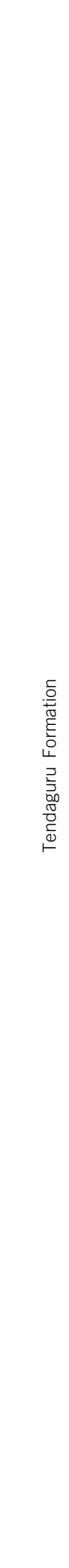 } & \multirow{9}{*}{$\begin{array}{l}\text { Upper Dinosaur } \\
\text { Member }\end{array}$} & Upper Saurian Bed & $\begin{array}{l}\text { Taele (1934); Wade (1937); Haughton (1938); Arkell (1956); } \\
\text { Quennell et al. (1956); Aitken (1956b, 1961); Russell et al. } \\
\text { (1980); Raath \& Mclntosh (1987); Heinrich (1999a); } \\
\text { Bonaparte et al. (2000); Heinrich et al. (2001); } \\
\text { Aberhan et al. (2002); Schrank (2004, 2005) }\end{array}$ \\
\hline & & Oberer Dinosaurier-Mergel & Hennig (1937a) \\
\hline & & Upper Reptile Horizon & Furon (1963) \\
\hline & & Oberes Saurier-Lager & Hölder (1964) \\
\hline & & Upper Saurian Beds & Zils et al. (1995) \\
\hline & & Upper Saurian Member & Schlüter (1997) \\
\hline & & Upper Dinosaur Member & Schudack (1999); Schudack \& Schudack (2002) \\
\hline & & Obere Saurierschichten & Heinrich (2003); Sames (2005) \\
\hline & & Upper Saurian member & Sames (2008) \\
\hline & \multirow{22}{*}{$\begin{array}{l}\text { Indotrigonia afri- } \\
\text { cana Member }\end{array}$} & Trigonienschichten & Fraas (1908); Quennell et al. (1956) \\
\hline & & Trigonia Smeei-(Beyschlagi)-Schicht & Hennig (1914a) \\
\hline & & $\begin{array}{l}\text { Mittlere Sandsteinzone mit Trigonia } \\
\text { smeei }\end{array}$ & Janensch (1914c) \\
\hline & & Trigonia smeei-Schicht & Lange (1914); Zwierzycki (1914); Dietrich (1926, 1927a) \\
\hline & & Trigonia smeei zone & Lull (1915); Simpson (1926) \\
\hline & & Trigonia-smeei (-beyschlagi)-Horizont & Behrend (1918) \\
\hline & & $\begin{array}{l}\text { Middle marine sandstones with } \\
\text { Trigonia smeei }\end{array}$ & Schuchert (1918) \\
\hline & & Smeei-Stufe & Hennig (1924) \\
\hline & & Smeei-Schicht & Dietrich (1925a); Hennig (1927) \\
\hline & & Trigonia smeei-Horizont & Krenkel (1925) \\
\hline & & Trigonia smeei Bed & $\begin{array}{l}\text { Parkinson (1930b); Wade (1937); Haughton (1938); Quennell } \\
\text { et al. (1956); Aitken (1956b, 1961); Cox (1965); Heinrich } \\
\text { (1999a); Bonaparte et al. (2000); Heinrich et al. (2001); } \\
\text { Aberhan et al. (2002); Bussert \& Aberhan (2004); Schrank } \\
\text { (2004, 2005); Msaky (2007) }\end{array}$ \\
\hline & & Smeei Bed & Teale (1934); Arkell (1956) \\
\hline & & Trigonia smeei Beds & Teale (1934); Furon (1963) \\
\hline & & Smeei-Zone & Hennig (1937a) \\
\hline & & Trigonia smeei-Zone & Krenkel (1957) \\
\hline & & $\begin{array}{l}\text { Schichten mit Trigonia mandavae } \\
\text { (smeei auct.) }\end{array}$ & Hölder (1964) \\
\hline & & Indotrigonia africana Bed & Raath \& McIntosh (1987) \\
\hline & & Smeei Beds & Zils et al. (1995) \\
\hline & & Trigonia smeei Member & Schlüter (1997) \\
\hline & & Smeei Member & Schudack (1999); Schudack \& Schudack (2002) \\
\hline & & Trigonia smeei-Schichten & Heinrich (2003); Sames (2005) \\
\hline & & Trigonia smeei member & Sames (2008) \\
\hline & \multirow{5}{*}{$\begin{array}{l}\text { Middle Dinosaur } \\
\text { Member }\end{array}$} & Mittlerer Saurier-Horizont & $\begin{array}{l}\text { Hennig (1914a); Zwierzycki (1914); Behrend (1918); Krenkel } \\
\text { (1925) }\end{array}$ \\
\hline & & Mittlere (zweite) Saurierzone & Janensch (1914c) \\
\hline & & Mittlere Saurierschicht & Dietrich (1914, 1925a); Hennig (1914b, 1914c) \\
\hline & & Mittlere Sauriermergel & Janensch (1914c) \\
\hline & & Middle dinosaur horizon & Lull (1915) \\
\hline
\end{tabular}


Table 2. continued

\begin{tabular}{|c|c|c|c|}
\hline \multicolumn{2}{|c|}{ Proposed names } & Previous names & Literature \\
\hline \multirow{36}{*}{ 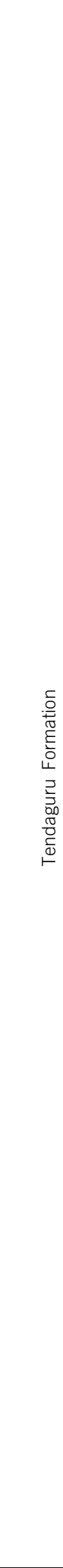 } & \multirow{18}{*}{$\begin{array}{l}\text { Middle Dinosaur } \\
\text { Member }\end{array}$} & Middle or second dinosaur zone & Schuchert (1918) \\
\hline & & Saurier-Horizont II & Behrend (1918) \\
\hline & & Middle Reptile Bed & Gregory (1921); Parkinson (1930b); Wade (1937). \\
\hline & & Mittlere Saurier-Schicht & Hennig (1924, 1937a, 1937b); Dietrich (1927a) \\
\hline & & Middle dinosaur beds & Simpson (1926) \\
\hline & & Middle Saurian Bed & $\begin{array}{l}\text { Parkinson (1930b); Teale (1934); Wade (1937); Haughton } \\
\text { (1938); Arkell (1956); Quennell et al. (1956); Aitken (1961); } \\
\text { Russell et al. (1980); Raath \& Mclntosh (1987); Heinrich } \\
\text { (1999a); Bonaparte et al. (2000); Heinrich et al. ( 2001); } \\
\text { Aberhan et al. (2002); Schrank (2004, 2005) }\end{array}$ \\
\hline & & Mittlerer Sauriermergel & Dietrich (1933a, 1933b); Krenkel (1957) \\
\hline & & Middle Saurian Horizon & Teale (1934) \\
\hline & & Mittlerer Dinosaurier-Mergel & Hennig (1937a) \\
\hline & & Middle Reptile Horizon & Furon (1963) \\
\hline & & Mittleres Saurier-Lager & Hölder (1964) \\
\hline & & Middle Saurian Beds & Zils et al. (1995) \\
\hline & & Middle Saurian Member & Schlüter (1997) \\
\hline & & Middle Dinosaur Member & Schudack (1999); Schudack \& Schudack (2002) \\
\hline & & Mittlere Saurier-Schichten & Heinrich (2003) \\
\hline & & Mittlere Saurierschichten & Sames (2005) \\
\hline & & Middle Dinosaur Bed & Msaky (2007) \\
\hline & & Middle Saurian member & Sames (2008) \\
\hline & \multirow{18}{*}{ Nerinella Member } & Nerineen-Schicht & Hennig (1914a); Dietrich (1914, 1927a); Krenkel (1925) \\
\hline & & Untere Sandsteinzone, Nerineenzone & Janensch (1914c) \\
\hline & & Nerineenschicht & $\begin{array}{l}\text { Zwierzycki (1914); Janensch \& Hennig (1914); Behrend } \\
\text { (1918); Dietrich (1925a) }\end{array}$ \\
\hline & & Nerinea zone & Lull (1915); Simpson (1926) \\
\hline & & Nerineen-Schichten & Behrend (1918) \\
\hline & & Lower or Nerinea sandstones & Schuchert (1918) \\
\hline & & Nerineen-Stufe & Hennig (1924) \\
\hline & & Unterer Saurier-Horizont & Krenkel (1925) \\
\hline & & Nerinea Bed & $\begin{array}{l}\text { Parkinson (1930b); Teale (1934); Wade (1937); } \\
\text { Haughton (1938); Quennell et al. (1956); Aitken (1961); } \\
\text { Raath \& McIntosh (1987); Heinrich (1999a); } \\
\text { Bonaparte et al. (2000); Heinrich et al. (2001); } \\
\text { Aberhan et al. (2002); Schrank (2004, 2005); Msaky (2007) }\end{array}$ \\
\hline & & Nerinean Horizon & Teale (1934) \\
\hline & & Nerinellen-Zone & Hennig (1937a, 1937b); Krenkel (1957) \\
\hline & & $\begin{array}{l}\text { Nerinella bed: sandstone with } \\
\text { Trigonia dietrichi }\end{array}$ & Arkell (1956) \\
\hline & & Nerinea Beds & Furon (1963); Zils et al. (1995) \\
\hline & & Nerinellen-Bänke & Hölder (1964) \\
\hline & & Nerinella Bed & Cox (1965) \\
\hline & & Nerinea Member & $\begin{array}{l}\text { Schlüter (1997); Schudack (1999); Schudack \& Schudack } \\
\text { (2002) }\end{array}$ \\
\hline & & Nerineenschichten & Heinrich (2003); Sames (2005) \\
\hline & & Nerinea member & Sames (2008) \\
\hline
\end{tabular}


Table 2. continued

\begin{tabular}{|c|c|c|c|}
\hline \multicolumn{2}{|c|}{ Proposed names } & Previous names & Literature \\
\hline \multirow{21}{*}{ 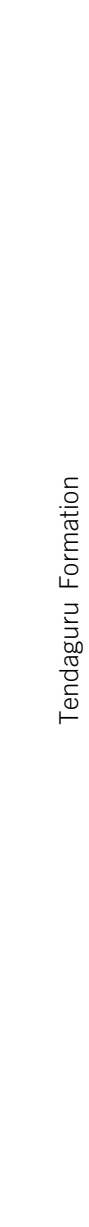 } & \multirow{21}{*}{$\begin{array}{l}\text { Lower Dinosaur } \\
\text { Member }\end{array}$} & Unterster Saurier-Horizont & Hennig (1914a); Zwierzycki (1914) \\
\hline & & Untere Saurier-Schicht & $\begin{array}{l}\text { Dietrich (1914, 1925a, 1927a); Hennig (1924, } \\
\text { 1937a) }\end{array}$ \\
\hline & & Untere (erste) Saurierzone & Janensch (1914c) \\
\hline & & Untere Sauriermergel & Janensch (1914c); Krenkel (1957) \\
\hline & & Lower dinosaur horizon & Lull (1915) \\
\hline & & Unterer Saurierhorizont & Behrend (1918) \\
\hline & & Lower or first dinosaur sandy marl & Schuchert (1918) \\
\hline & & Lower Reptile Bed & Gregory (1921); Parkinson (1930b); Wade (1937) \\
\hline & & Unterer Saurier-Horizont & Krenkel (1925) \\
\hline & & Lower dinosaur beds & Simpson (1926) \\
\hline & & Lower Saurian Bed & $\begin{array}{l}\text { Parkinson (1930b); Teale (1934); Wade (1937); Haughton } \\
\text { (1938); Arkell (1956); Quennell et al. (1956); Aitken (1961) } \\
\text { Raath \& MacIntosh (1987); Heinrich (1999a); Bonaparte } \\
\text { et al. (2000); Heinrich et al. (2001); Aberhan et al. (2002); } \\
\text { Schrank (2004, 2005) }\end{array}$ \\
\hline & & Lower Saurian Horizon & Teale (1934) \\
\hline & & Unterer Dinosaurier-Mergel & Hennig (1937a) \\
\hline & & Lower Reptile Horizon & Furon (1963) \\
\hline & & Unteres Saurier-Lager & Hölder (1964) \\
\hline & & Lower Saurian Beds & Zils et al. (1995) \\
\hline & & Lower Saurian Member & Schlüter (1997); Russell et al. (1980) \\
\hline & & Lower Dinosaur Member & Schudack (1997); Schudack \& Schudack ( 2002) \\
\hline & & Untere Saurierschichten & Heinrich (2003); Sames (2005) \\
\hline & & Lower Dinosaur Bed & Msaky (2007) \\
\hline & & Lower Saurian member & Sames (2008) \\
\hline
\end{tabular}

lagoonal, the Nerinea Bed, Trigonia smeei Bed, and Trigonia schwarzi Bed as marginal marine in origin (see also Hennig 1912b). Dietrich (1933a) considered the dinosaur beds as lagoonal-estuarine strata. Reck (1925) argued that the dinosaur-bearing beds were deposited in saline marshes. Parkinson (1930a) interpreted the palaeo-environment of the Tendaguru Beds below the Trigonia schwarzi Bed as an estuary.

Throughout its range, the Tendaguru Beds have yielded abundant fossils including vertebrates, invertebrates, and plants from deposits of alternating marginal marine and continental environments. The three dinosaur-bearing deposits are of particular importance because they have produced rich assemblages of dinosaurs referable to Sauropoda, Ornithopoda and Theropoda (e.g. Janensch 1914c, 1925a, 1929a, 1955, 1961a; Hennig 1925; for details see below). Invertebrates are mainly reported from the three marine divisions and include, for example, corals, bivalves, gastropods, cephalopods, arthropods, and brachiopods (e.g. Dietrich 1914, 1933a; Lange 1914; Zwierzycki 1914; Quennell et al. 1956; Aitken 1961; Cox 1965; for details see below). In the three dinosaur-bearing beds, invertebrate fossils are far less common (Hennig 1914b). Fossil plant remains were also described (e.g. Gothan 1927; Kahlert et al. 1999; Stockey 1978; Schrank 1999, 2005; Süss \& Schultka 2006).

The age of the Tendaguru Beds has been a subject of much debate for many years and opinions vary considerably (e.g. Fraas 1908; Janensch 1914a; Dietrich 1925a, 1933a; Kitchin 1929; Hennig 1924, 1927, 1937a, 1937b; Simpson 1926; Arkell 1956; Quennell et al. 1956; Aitken 1961; Kent et al. 1971). For the purposes of the present report it is not necessary to discuss all these views in detail, because many of them are now obsolete. A review of the dating of the Tendaguru Beds in the early stages of research was given by Hennig (1937a), Quennell et al. (1956), Aitken (1961: tab. 2), and Sames (2008: tab. 1).

The Tendaguru Beds consist of a Late Jurassic part, comprising the Lower Saurian Bed, Nerinea Bed, Middle Saurian Bed, Trigonia smeei Bed, and the Upper Saurian Bed, and an Early Cretaceous part, the Trigonia schwarzi Bed (e.g. Dietrich 1927a, 1933a, 1933b; Spath 1928-1933; Aitken 1961; Heinrich et al. 2001; Aberhan et al. 2002). In contrast, some authors included the 
whole Upper Saurian Bed (e.g. Hennig 1914a; Janensch 1914a; Lange 1914; Zwierzycki 1914; Sames 2008) or parts of it (e.g. Hennig 1937a) into the Early Cretaceous (Neocomian).

Originally, published ages for the marine stratigraphic units were primarily based on ammonites and bivalves (Trigonia). Later, palynomorphs and ostracods yielded new insights into the age of some of these units (Schrank 2004, 2005; Msaky 2007; Sames 2008). The age determination of the dinosaur-bearing deposits mainly relied on the interfingering relationships with the marine strata of the Tendaguru Beds. More recently, palynomorphs, charophytes, and ostracods have yielded useful biostratigraphical criteria (Schudack 1999; Schudack \& Schudack 2002; Schrank 2004, 2005; Sames 2008).

On biostratigraphical grounds, Dietrich (1933a, 1933b) subdivided the Tendaguru Beds into (1) the Late Jurassic "Smeeistufe" (smeei Stage), comprising strata from the Trigonia dietrichi Sandstone (basal part of the Nerinea Bed) up to the Upper Saurian Bed, regarded as Sequanian (late Oxfordian) to early Portlandian (early Tithonian) in age; and (2) the Early Cretaceous "Schwarzistufe" (schwarzi Stage) represented by the Trigonia schwarzi and Trigonia bornhardti sandstone. The schwarzi Stage was considered to be late Valanginian to early Aptian in age (Dietrich 1933a, 1933b). A more sophisticated biostratigraphic subdivision of the Tendaguru Beds ("Vor-smeei-Lager", "Mittleres Dinosaurier-Lager", "Haupt-smeei-Lager", "Oberes Dinosaurier-Lager", "Spät-smeei-Lager", “Trigonia bornhardti-Schicht”, "Trigonia schwarzi-Schicht”) was provided by Hennig (1937a). A detailed account of age ranges is given below in the characterisation of the various members of the Tendaguru Formation.

In the hinterland of Lindi, the Tendaguru Beds are overlain by the Makonde Beds (Janensch 1914a), a term which was first applied by Bornhardt (1900) for a sequence of strata in southern Tanzania that mainly consists of conglomerate, sandstone and intercalated siltstone, silty sand and clay as well as red sandy beds of possibly Aptian (e.g. Hennig 1914a; Janensch 1914a; Behrend 1918; Krenkel 1925), possibly late Aptian (e.g. Aitken 1961) or middle Aptian to middle Albian age (Veeken \& Titov 1996). The transition from the Trigonia schwarzi Bed into both the late Aptian marine Kiturika Beds and the predominantly continental Makonde Beds was described by Hennig (1914a, 1937a) from several localities in the hinterland of Lindi and Kilwa. Aitken (1961), however, also recorded sites without this upward sequence (see also Kent et al. 1971). Parkinson (1930b), who had compared the Tendaguru Beds and the Makonde Beds on the basis of their heavy mineral contents, concluded that the Makonde Beds from the Noto Plateau are "in reality much younger than hitherto supposed". More recent investigations in the Rovuma Basin (northern Mozambique) suggest a late Aptian-early Albian age for the Makonde Formation (Hancox et al. 2002). Janensch (1914a) referred the Tendaguru Beds along with the "Makon- deschichten" (Makonde Beds) to the "Lindiformation" (Lindi Formation), a stratigraphic term, which was introduced by Dacqué \& Krenkel (1909), but now is regarded as having been superseded (Quennell et al. 1956).

\section{Geological setting}

The Tendaguru area is situated in the southwestern part of the Mandawa Basin that forms an embayment of the Somali Basin (Kent et al. 1971; Scrutton et al. 1981; Veeken \& Titov 1996; Mpanda 1997). The Mandawa Basin is underlain by Neoproterozoic gneiss (Hennig 1914a; Veeken \& Titov 1996). The basin evolution is closely related to plate tectonic processes and the gradual break-up of Gondwana that commenced in the latest Carboniferous/Early Permian with the formation of the East African continental Karroo rift system (Schandelmeier et al. 2004; Nicholas et al. 2007). The oldest sediments belong to the Karroo Supergroup. They mainly consist of fluvial and lacustrine deposits with occasional local marine incursions, the age of which ranges from the Permo-Carboniferous to the Early Jurassic (Kreuser et al. 1990; Wopfner 1992; Balduzzi et al. 1992; Hankel 1994).

Local, restricted marine or coastal to marine conditions in the subsiding Mandawa Basin resulted in the deposition of evaporites (e.g. gypsum, halite, anhydrite) with silty shales from the Triassic to the Early Jurassic (e.g. Upper Pindiro Evaporites: Kagya 1996; Nondwa Evaporite: Veeken \& Titov 1996). During the Jurassic, Madagascar and other parts of East Gondwana rifted gradually away from the region of what is now Tanzania, Kenya and Somalia (Kent et al. 1971; Reeves et al. 2002; Geiger et al. 2004; Schandelmeier et al. 2004; Rabinowitz \& Woods 2006; Nicholas et al. 2007). This continental break-up is assumed to have commenced in the Middle Jurassic (e.g. Hankel 1994; Salman \& Abdula 1995; Veeken \& Titov 1996). There is some evidence, however, that Madagascar possibly already separated during the late Early Jurassic (Toarcian) (Geiger et al. 2004; Geiger \& Schweigert 2006).

As a result, the Tethys Ocean spread into the rift zone between Gondwana and Madagascar from the north (Scrutton et al. 1981; Hankel 1994; Luger et al. 1994; Mpanda 1997) and flooded the Somali Basin and the Mandawa sub-basin during the Bajocian, which saw two major episodes of eustatic sea level rise (Hallam 2001). With the onset of sea floor spreading, the Somali Basin developed into the passive Tanzanian continental margin (Mpanda 1997).

A regression during the early Bathonian was followed by the main Jurassic transgression in the late Bathonian which extended widely over East Africa and continued at least until the Kimmeridgian-Tithonian (Luger et al. 1994). Marine shales with intercalated evaporites of Callovian age are reported from the Mandawa Basin (e.g. Mandawa-7 well; Mpanda 1997). The 
cyclic depositional character of the Upper Jurassic and Lower Cretaceous sediments of the Mandawa Basin such as the Tendaguru Beds suggests control by eustatic sea-level changes (Aberhan et al. 2002).

In the early Early Cretaceous, an unconformity developed in the Mandawa Basin owing to uplift and widespread drop of the sea level (Aitken 1961; Mpanda 1997; Aberhan et al. 2002). This basin-wide regression occurred apparently in the Valanginian to middle Aptian (Mpanda 1997) or during the Aptian (Veeken \& Titov 1996) but did not likely affect the Mandawa area (Mpanda 1997). During the late Early Cretaceous the sediments of the Makonde Formation were predominantly deposited in fluvial to marginal marine environments.

The time span from the Late Cretaceous (Santonian) to Early Oligocene, which was characterised by exceptional tectonic stability of the Tanzanian coastal region (Kent et al. 1971), led to the deposition of the Kilwa Group (Nicholas et al. 2006). The end of the Kilwa Group deposition occurred in the Oligocene and corre- sponds with the top of the Pande Formation (Nicholas et al. 2007), and it indicates the termination of the Tanzanian continental passive margin. It was followed by the reactivation of older Mesozoic faults and the creation of new faults during the Neogene (Nicholas et al. 2007).

\section{Methods}

This study is based on all available information from the Tendaguru Beds. In particular, this comprises data of the GTE (including unpublished original field notes, the so-called field catalogue of Janensch which is housed at the Museum für Naturkunde Berlin) and data of the GTTE (see Aberhan et al. 2002 for the methods applied). In establishing a formal lithostratigraphy of the Tendaguru Beds we follow the guidelines of the International Subcommission on Stratigraphic Classification (Murphy \& Salvador 1999), one exception being the naming of the members. While the guidelines recommend the usage of an appropriate geographic name in naming lithostratigraphic units, we refer to the original names for the various subunits of the Tendaguru Beds. This has two reasons: (1) several members are defined in the Tingutinguti stream section and no geographic

Table 3. Geographic coordinates [GPS data, UTM system, datum: New (1960) Arc] of samples of the Tendaguru Formation mentioned in the text. For stratigraphic position of samples see Figure 3 and Aberhan et al. (2002: fig. 2).

\begin{tabular}{|c|c|c|c|}
\hline Sample number & Stratigraphy and locality & Easting (UTM) & Northing (UTM) \\
\hline Dwa 8 & Upper Dinosaur Member, Dwanika stream bed & 37 L 0524703 & 8927488 \\
\hline Dwa 7 & Upper Dinosaur Member, Dwanika stream bed & 37 L 0524678 & 8927524 \\
\hline Dwa 6 & Upper Dinosaur Member, Dwanika stream bed & 37 L 0524651 & 8927573 \\
\hline Dwa 5 & Upper Dinosaur Member, Dwanika stream bed & 37 L 0524649 & 8927573 \\
\hline Dwa 3 & Upper Dinosaur Member, Dwanika stream bed & 37 L 0524593 & 8927611 \\
\hline Dwa 2 & Upper Dinosaur Member, Dwanika stream bed & 37 L 0524579 & 8927632 \\
\hline Dwa 1 & Upper Dinosaur Member, Dwanika stream bed & 37 L 0524516 & 8927655 \\
\hline Dwa A & Upper Dinosaur Member, Dwanika stream bed & 37 L 0524417 & 8927788 \\
\hline Tin $11 b$ & Upper Dinosaur Member, Tendaguru Hill & 37 L 0524625 & 8927092 \\
\hline Tin 11a & Upper Dinosaur Member, Tendaguru Hill & 37 L 0524606 & 8927066 \\
\hline Tin $10 f$ & Upper Dinosaur Member, Tingutinguti stream bed & 37 L 0524606 & 8927024 \\
\hline Tin 10e & Upper Dinosaur Member, Tingutinguti stream bed & 37 L 0524635 & 8926922 \\
\hline Tin 10d & Upper Dinosaur Member, Tingutinguti stream bed & 37 L 0524574 & 8926830 \\
\hline Tin $9 w$ & Indotrigonia africana Member, Tingutinguti stream bed & 37 L 0524479 & 8926730 \\
\hline $\operatorname{Tin} 9 u$ & Indotrigonia africana Member, Tingutinguti stream bed & 37 L 0524422 & 8926736 \\
\hline Tin $9 r$ & Indotrigonia africana Member, Tingutinguti stream bed & 37 L 0524323 & 8926772 \\
\hline Tin $9 p$ & Indotrigonia africana Member, Tingutinguti stream bed & 37 L 0524316 & 8926766 \\
\hline $\operatorname{Tin} 71$ & Middle Dinosaur Member, Tingutinguti stream bed & 37 L 0524174 & 8926630 \\
\hline Tin $7 k$ & Middle Dinosaur Member, Tingutinguti stream bed & 37 L 0524150 & 8926614 \\
\hline Tin $7 \mathrm{~h}$ & Middle Dinosaur Member, Tingutinguti stream bed & 37 L 0524024 & 8926508 \\
\hline $\operatorname{Tin} 7 f$ & Middle Dinosaur Member, Tingutinguti stream bed & 37 L 0524050 & 8926468 \\
\hline Tin $7 e$ & Middle Dinosaur Member, Tingutinguti stream bed & 37 L 0524034 & 8926472 \\
\hline Tin $7 d$ & Middle Dinosaur Member, Tingutinguti stream bed & 37 L 0524034 & 8926347 \\
\hline Tin $6 a$ & Middle Dinosaur Member, Tingutinguti stream bed & 37 L 0524025 & 8926340 \\
\hline Tin $4 \mathrm{~h}$ & Nerinella Member, Tingutinguti stream bed & 37 L 0523938 & 8926260 \\
\hline $\operatorname{Tin} 3 a$ & Nerinella Member, Tingutinguti stream bed & 37 L 0523846 & 8926220 \\
\hline Tin 2 & Nerinella Member, Tingutinguti stream bed & 37 L 0523846 & 8926230 \\
\hline Tin 1 & Lower Dinosaur Member, Tingutinguti stream bed & 37 L 0523681 & 8926216 \\
\hline Tin $\mathrm{Oa}$ & Lower Dinosaur Member, Tingutinguti stream bed & 37 L 0523827 & 8926078 \\
\hline
\end{tabular}


names are available to distinguish between the type localities; and (2) the original terms are firmly anchored in the literature. In such a case, section B.3.g of the International Stratigraphic Guide (Murphy \& Salvador 1999) allows for the preservation of traditional or wellestablished names provided that they are well defined.

The definition of type sections presented herein rests on a detailed sedimentological survey of the Tingutinguti (Tin, Kit) and Dwanika (Dwa) stream sections at Tendaguru (Fig. 1) by the GTTE. Recorded parameters include lithology, grain-size, texture, sedimentary structures, geometry of the strata, trace fossils and bioturbation intensity. The smallest stratigraphic unit recognised are individual beds. They are labelled according to the acronym of the stream section and are numbered consecutively (see Table 3 ). Occasionally, such a numbered unit may cover up to a few meters in thickness and comprises several successional beds of uniform lithology.

When citing other authors' age assignments of a stratigraphical unit, we used the age as provided in the original paper. We are well aware of the fact that the stratigraphical nomenclature for the Late Jurassic was not used consistently over the past 100 years of research on the Tendaguru Beds. By keeping the original ages, however, the corresponding discussion remains reproducible. Note, for instance, that the middle Kimmeridgian is abandoned and is now included in the late Kimmeridgian and that the Portlandian can be equated with the Tithonian.

In the context of palaeoenvironmental interpretations we draw on palaeoecological data as far as they are directly relevant. A more detailed palaeoecological interpretation, including the palaeobiology of the Tendaguru dinosaurs, was given in Aberhan et al. (2002) and is not repeated here.

\section{Description of lithostratigraphic units}

\section{Tendaguru Formation}

Figure 2, Table 1

Based on previous and current data (e.g. Hennig 1914a; Janensch 1914a; Aberhan et al. 2002; Bussert \& Aberhan 2004), the Tendaguru Formation is subdivided into six members, which are renamed here as follows (from bottom to top): Lower Dinosaur Member [formerly "Untere (erste) Saurierzone", Lower Saurian Bed], Nerinella Member [formerly "Untere Sandsteinzone (Nerineenzone)", Nerinea Bed], Middle Dinosaur Member [formerly "Mittlere (zweite) Saurierzone", Middle Saurian Bed], Indotrigonia africana Member [formerly "Mittlere Sandsteinzone mit Trigonia smeei", Trigonia smeei Bed], Upper Dinosaur Member [formerly "Oberste (dritte) Saurierzone", Upper Saurian Bed], and Rutitrigonia bornhardti-schwarzi Member [formerly “Obere Sandsteinzone mit Trigonia schwarzi”, Trigonia schwarzi Bed].

Name. The name of the formation was derived from Tendaguru, which means steep hill in the language of the Wamwera tribe. The series of strata that now makes up the Tendaguru Formation was previously named "Tendaguruschichten" (Hennig 1914a; Janensch 1914c). Here, we formally raise the succession of strata to formation rank and change this name and other, previously applied terms to Tendaguru Formation (Table 1). Note that the term Tendaguru Formation was previously suggested by Schudack (1999) but the author failed to describe and define the formation. Terms such as Tenda- guru Series (e.g. Schuchert 1918; Wade 1937; Aitken 1961; Mpanda 1997) or Tendaguru Group (Schlüter 1997) are also abandoned here (Table 1).

Type section. Tendaguru Hill located in the Mbemkuru Valley in the southern coastal area of Tanzania is regarded as type locality (Quennell et al. 1956). However, neither the GTE nor the BTE designated a type section for the Tendaguru Beds now named Tendaguru Formation. Here, the Tendaguru Formation is formally typified along the Tingutinguti and Dwanika stream sections (Fig. 1). Owing to the lack of complete and extended sections through the formation from bottom to top, a composite type section for the Tendaguru Formation is established and defined from the following beds: Tin 1 to Tin 10e, Dwa 1 to Dwa 7, Tin 11a to Tin 11d, and Kit 6 to Kit 8 (Fig. 3, Table 3).

Distribution. The sediments of the Tendaguru Formation are located in an approximately north-south trending belt of predominantly Jurassic to Cretaceous rocks in the southern coastal area of Tanzania. The Tendaguru Formation is best exposed in the surroundings of Tendaguru Hill (Figs 1,4A). Confirmed or supposed equivalents occupy larger parts of (1) the Mbemkuru river valley and adjacent regions (Tendaguru area); (2) the Mandawa-Mahokondo area; and (3) the Makangaga (south)-Ruawa area, covering approximately $2000 \mathrm{~km}^{2}$ (Hennig 1914a, 1937a). Altogether, outcrops of the Tendaguru Formation are found from Matandu river in the north to Lake Lutambo in the south. Mapping by the GTE resulted in a geological map (scale: $1: 300,000)$ showing the generalised distribution of the Tendaguru Formation in these areas (Hennig 1914a).

Subsequent exploration has confirmed most of the mapping performed by the GTE but also challenged some conclusions relating the distribution and correlation of the members of the Tendaguru Formation (Quennell et al. 1956; Aitken 1961).

Considering these limitations, the southernmost occurrences of the Tendaguru Formation, mapped as Upper Dinosaur Member, are located east and northeast of Lake Lutambo approximately $25 \mathrm{~km}$ west of the seaport of Lindi (Fig. 1) (Hennig 1914a: geological map). The northernmost outcrops of the Tendaguru Formation, also mapped as Upper Dinosaur Member, are found near Mitole at the Matandu river roughly $36 \mathrm{~km}$ west of Kilwa-Kinvinje (Fig. 1) (Hennig 1914a: geological map). The Tendaguru Formation has been traced southwestward as far as the Mavudyi river region (mapped as Rutitrigonia bornhardti-schwarzi Member) and Likoniengwale river regions (mapped as Upper Dinosaur Member but not shown in Figure 1 due to position of inlay), and its easternmost occurrence is an outlier located at the western slope of Kitulo Hill near Lindi where Lower Cretaceous deposits with Rutitrigonia schwarzi are exposed (Hennig 1937a). Generally, scattered outcrops of the Tendaguru Formation far north of the Mbemkuru river, such as in the Makangaga (south)-Ruawa region, are difficult to correlate with the 


\begin{tabular}{|c|c|c|c|c|}
\hline Epoch & Stage & Formation & Member & Lithology \\
\hline \multirow{2}{*}{ 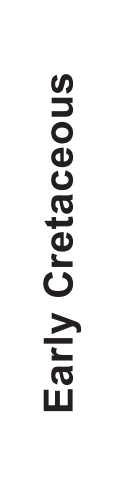 } & $\begin{array}{l}\text { Aptian } \\
\text { to } \\
\text { early Albian }\end{array}$ & $\begin{array}{l}\text { Makonde } \\
\text { Formation }\end{array}$ & & $\begin{array}{l}\text { Fine- to medium-grained sandstones, red } \\
\text { to purple, intercalated conglomerates, silt } \\
\text { stones, silty sandstones and claystones. } \\
\qquad \sim 200 \mathrm{~m}\end{array}$ \\
\hline & $\begin{array}{l}\text { Valanginian } \\
\text { to } \\
\text { Hauterivian }\end{array}$ & \multirow{7}{*}{$\begin{array}{l}\text { Tendaguru } \\
\text { Formation }\end{array}$} & $\begin{array}{c}\text { Rutitrigonia } \\
\text { bornhardti- } \\
\text { schwarzi } \\
\text { Member }\end{array}$ & $\begin{array}{l}\text { Fine- to medium-grained sandstones } \\
\text { with molluscs, echinoderms and variable } \\
\text { amounts of calcite. At the base a con- } \\
\text { glomerate bed consisting of quartz } \\
\text { pebbles and sedimentary lithoclasts. } \\
\qquad 5 \mathrm{~m} \text { to } 70 \mathrm{~m}\end{array}$ \\
\hline \multicolumn{2}{|c|}{ unconformity } & & \multicolumn{2}{|r|}{ unconformity } \\
\hline \multirow{5}{*}{ 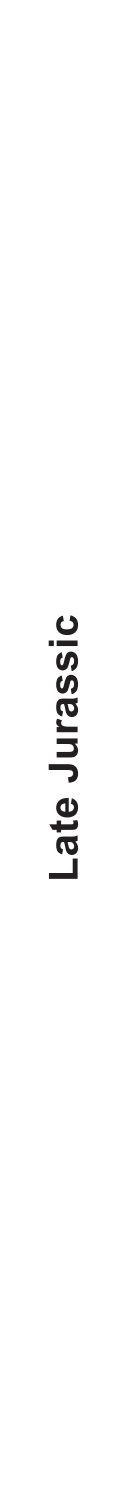 } & Tithonian & & $\begin{array}{l}\text { Upper } \\
\text { Dinosaur } \\
\text { Member }\end{array}$ & $\begin{array}{l}\text { Mainly ripple cross-bedded, fine- } \\
\text { grained, calcareous sandstones and } \\
\text { siltstones with intercalated claystone } \\
\text { beds and isolated micritic carbonates, } \\
\text { partly dolomites. Dinosaur bones. } \\
\sim 32 \mathrm{~m}\end{array}$ \\
\hline & $\begin{array}{l}\text { late } \\
\text { Kimmeridgian } \\
\text { to } \\
\text { Tithonian }\end{array}$ & & $\begin{array}{c}\text { Indotrigonia } \\
\text { africana } \\
\text { Member }\end{array}$ & $\begin{array}{l}\text { Brown to grey, calcite-cemented, } \\
\text { bioclast- and feldspar-rich sandstones. } \\
\text { Conglomerate beds, thin clay- and } \\
\text { siltstone layers and sandy limestones. } \\
\text { Sandstones interfinger with oolithic } \\
\text { limestones in upper part of the suc- } \\
\text { cession (e.g., NE of Tendaguru Hill). } \\
20 \mathrm{~m} \text { to } 50 \mathrm{~m}\end{array}$ \\
\hline & $\begin{array}{c}\text { late } \\
\text { Kimmeridgian }\end{array}$ & & $\begin{array}{l}\text { Middle } \\
\text { Dinosaur } \\
\text { Member }\end{array}$ & $\begin{array}{l}\text { Mainly light grey, ripple cross-bedded, } \\
\text { fine-grained, calcareous sandstones and } \\
\text { siltstones and massive to crudely bedded } \\
\text { silt- and claystones. Dinosaur bones. } \\
13 \mathrm{~m} \text { to } 30 \mathrm{~m}\end{array}$ \\
\hline & $\begin{array}{l}\text { Oxfordian } \\
\text { to } \\
\text { Kimmeridgian }\end{array}$ & & $\begin{array}{l}\text { Nerinella } \\
\text { Member }\end{array}$ & $\begin{array}{l}\text { Trough cross-bedded or massive } \\
\text { sandstones, partly fossiliferous. } \\
\text { Well sorted, planar to low-angle } \\
\text { cross-bedded as well as isolated } \\
\text { swaley cross-bedded sandstones. } \\
\qquad 5 \mathrm{~m} \text { to } 45 \mathrm{~m}\end{array}$ \\
\hline & $\begin{array}{l}\text { ? Callovian } \\
\text { to } \\
\text { middle } \\
\text { Oxfordian }\end{array}$ & & $\begin{array}{l}\text { Lower } \\
\text { Dinosaur } \\
\text { Member }\end{array}$ & $\begin{array}{l}\text { Upper part: Grey to green, ripple } \\
\text { cross-bedded, fine-grained, calcareous } \\
\text { sandstones and siltstones, both rich } \\
\text { in feldspar. Interbedded clay-rich } \\
\text { siltstones. Dinosaur remains. } \\
\quad>20 \mathrm{~m}\end{array}$ \\
\hline \multicolumn{5}{|c|}{ icontormity } \\
\hline \multicolumn{4}{|c|}{ Neoproterozoic } & gneiss \\
\hline
\end{tabular}

Figure 2. Stratigraphic succession and subdivision of the Tendaguru Formation in its type area. 


\section{SAMPLES STRATIGRAPHY DEPOSITIONAL \\ ENVIRONMENTS}

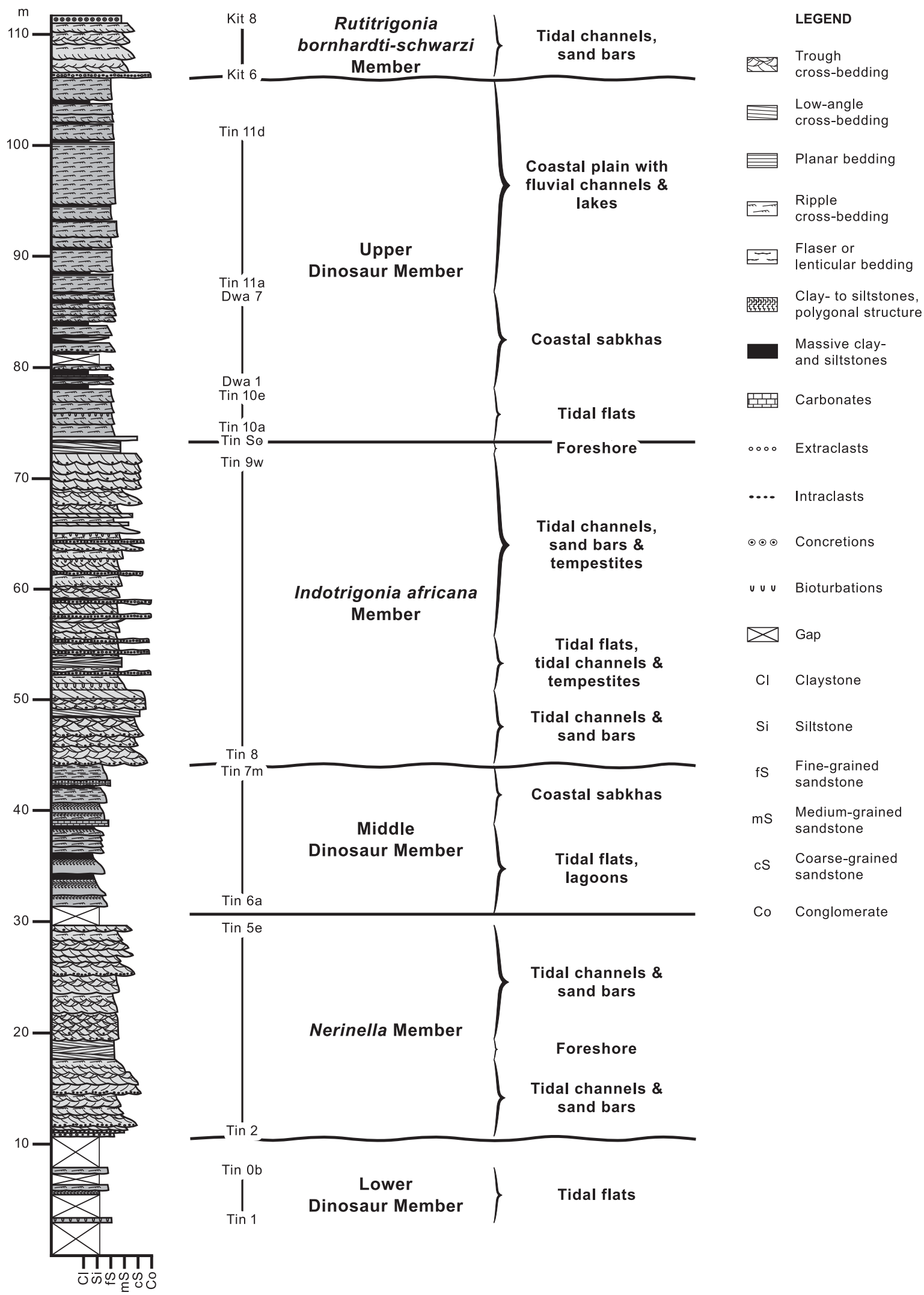

Figure 3. Composite section of the Tendaguru Formation in the type area. Sample numbers refer to samples of the German-Tanzanian Tendaguru Expedition 2000 (GTTE). Stratigraphic terms are defined in this study. For interpretation of depositional environments see text. For a complete depiction of the stratigraphic position of samples see Aberhan et al. (2002). 
standard sequence of strata in the Tendaguru area, because of the lack of adequate exposures and lithofacies deviations in the intervening areas. A detailed report of strata in the Mandawa-Mahokondo and Makangaga (south)-Ruawa areas which were referred to the Tendaguru Formation was given by Aitken (1961).

Thickness. The Tendaguru Formation shows remarkable variations in thickness due to the uneven surface on which it was deposited. In the surroundings of Tendaguru Hill the formation was measured by the GTTE at several localities in the Tingutinguti and Dwanika stream sections where its thickness exceeds $110 \mathrm{~m}$ (Aberhan et al. 2002). This approaches the thickness of approximately $125 \mathrm{~m}$ reported by Janensch (1914a) for the type area. These data contrast markedly with a total thickness of approximately $970 \mathrm{~m}$ given by Aitken (1961: tab. 4) for the equivalents of the Tendaguru Formation in the area of Mandawa-Mahokondo. Schlüter (1997) reported erroneously an estimated formation thickness of about $315 \mathrm{~m}$ in the type area. Overall, the thickness of the sandstonedominated marine members of the Tendaguru Formation increases distinctly towards the east, whereas that of the continental to marginal marine dinosaur-bearing members decreases in the same direction (Hennig 1937a).

Lithofacies. The fine-grained dinosaur-bearing members are dominated by ripple cross-bedded to massive siltstone as well as small-scale cross-bedded, finegrained sandstone with some claystone and carbonate layers. The sandstone is rich in feldspars and the matrix consists chiefly of calcite. The clay mineral fraction is dominated by smectite and illite (Aberhan et al. 2002). In contrast, the marine members consist mainly of siliciclastic, bioclast-rich, well-stratified and trough crossbedded sandstone, but low-angle and ripple crossbedded sandstone as well as flaser bedded heterolithic beds also occur (Aberhan et al. 2002).

Boundaries. The Tendaguru Formation is bounded at the base by an unconformity. The GTTE was unable to locate the basal contact owing to the lack of exposures, but Hennig (1914a) and Janensch (1914a) described the base of the Lower Dinosaur Member as unconformable on Neoproterozoic basement gneisses. Exposures showing this contact are rare. Basement gneisses at Ngwanya creek, located approximately $9 \mathrm{~km}$ south-southwest of Tendaguru Hill (Fig. 1), are reported to be overlain unconformably by deposits of the Lower Dinosaur Member (Hennig 1914a) but a detailed description of the basal unconformity was not given.
The Tendaguru Formation is unconformably overlain by the Makonde Formation that forms the top of several plateaus, for instance, the Namunda, Rondo, Noto, and Likonde-Kitale plateaus. However, at Tendaguru Hill and in its immediate surrounding erosion has removed any contacts that most probably previously existed between both formations. At the top of Tendaguru Hill, the Rutitrigonia bornhardti-schwarzi Member is capped by brownish fluvial sands and gravels which were tentatively identified as Mikindani Beds (now Mikindani Formation; Schlüter 1997) by Janensch (1914a), the age of which seems to be Pliocene or early Pleistocene (Schlüter 1997).

The time range of the hiatus between the Upper Dinosaur Member and the Rutitrigonia bornhardtischwarzi Member is still a matter of discussion (e.g. Schrank 2005; Sames 2008) and is probably not great. Following Aitken (1961) we therefore include all six sequences as members in one lithostratigraphic unit, the Tendaguru Formation, rather than treating the Rutitrigonia bornhardti-schwarzi Member as a separate formation as suggested by Arkell (1956).

Palaeontolgy. The Tendaguru Formation has yielded a variety of exceptional fossils. The land vertebrates are dominated by dinosaurs, notably Brachiosaurus (Janensch 1914c, 1929b, 1935, 1950a, 1950b, 1961a), Dicraeosaurus (Janensch 1914c, 1925a, 1929b), Kentrosaurus (Hennig 1915, 1916, 1925; Galton 1982a), Dysalotosaurus (Janensch 1955, 1961b; Galton 1977, 1981), and Elaphrosaurus (Janensch 1925a, 1929c; Galton 1982b) among others. Fishes (Hennig 1914c; Arratia et al. 2002), as yet unidentified sphenodontians (Heinrich 2003), a paramacellododid lizard (Broschinski 1999), crocodiles (Janensch 1914c; Heinrich et al. 2001), pterosaurs (Reck 1931; Unwin \& Heinrich 1999), and mammals (e.g. Dietrich 1927b; Simpson 1928; Heinrich 1998, 1999b) also occur. The recovered invertebrate assemblages include foraminifera (e.g. Fahrion 1937; Zils et al. 1995; Aberhan et al. 2002), corals (Weissermel 1900; Dietrich 1926), bivalves (e.g. Hennig 1914b; Lange 1914; Dietrich 1933a; Quennell et al. 1956; Aitken 1961; Cox 1965; Aberhan et al. 2002), gastropods (e.g. Hennig 1914b; Dietrich 1914, 1933a; Cox 1965; Aberhan et al. 2002), cephalopods (e.g. Zwierzycki 1914; Dietrich 1925a, 1933a; Spath 19281933; Aberhan et al. 2002), brachiopods (Lange 1914), arthropods (e.g. Beurlen 1933; Janensch 1933; Aberhan et al. 2002; Schudack \& Schudack 2002; Sames 2005,

Figure 4. Exposures of the Tendaguru Formation in its type area. A. Tendaguru Hill, view from the southeast; B. Low-angle crossbedded foreshore sandstone; Nerinella Member, Tingutinguti stream section (GTTE site Tin 4b-Tin 4d); C. Trough cross-bedded tidal channel sandstone; Nerinella Member, Tingutinguti stream section (Tin 4j); D. Fine-grained sandstone and siltstone of a tidal flat environment; Middle Dinosaur Member; Tingutinguti stream section (Tin 7f); E. Bioclast-rich coarse-grained tempestites; Indotrigonia africana Member; Tingutinguti stream section (Tin 9s); F. Fluvial and lacustrine/sabkha fine-grained sandstone, siltstone, and claystone; Upper Dinosaur Member; Dwanika stream section (Dwa 5); G. Trough and ripple cross-bedded tidal channel and bar sandstone; Rutitrigonia bornhardti-schwarzi Member, Tendaguru Hill (Kit 7); H. Ball-shaped sandstone concretions ("Kugelsandstein"), Rutitrigonia bornhardti-schwarzi Member, top of Tendaguru Hill (Kit 8). This figure is available in colour online at museum-fossilrecord.wiley-vch.de. 

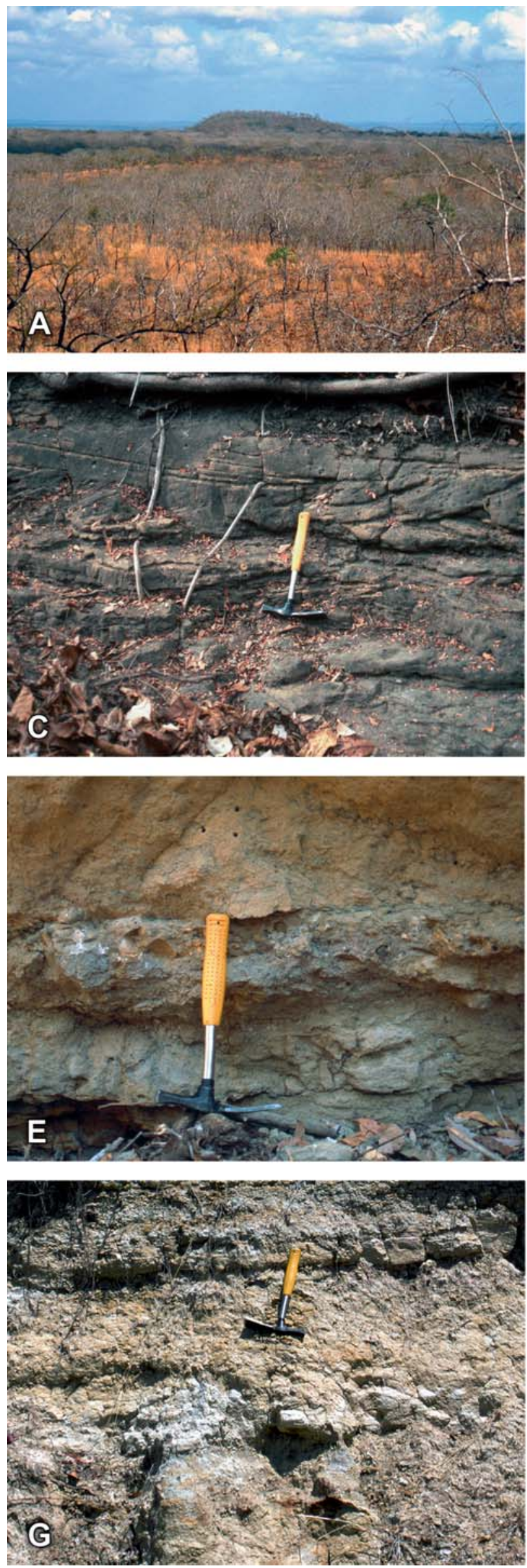
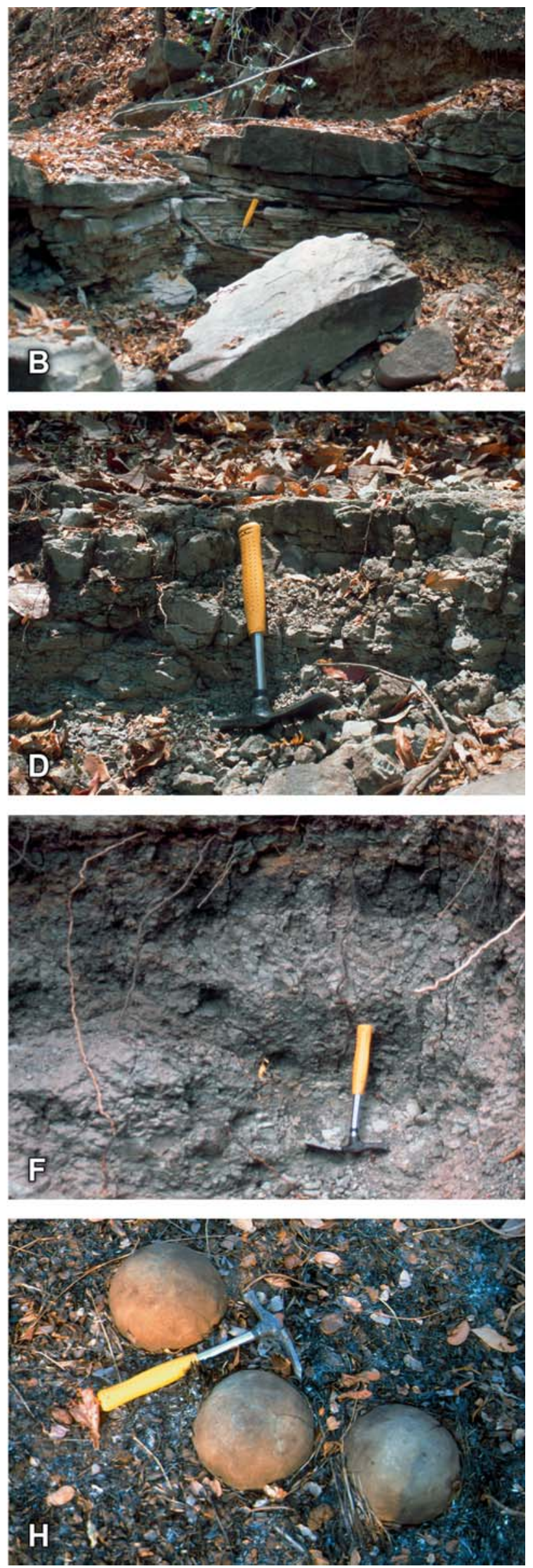
2008), crinoids (Sieverts-Doreck 1939; Aberhan et al. 2002), and annelids (Lange 1914). Fossil macroplant remains include a poorly preserved silicified conifer cone (Gothan 1927; Stockey 1978, 1982), silicified wood remains and fusain (e.g. Kahlert et al. 1999; Süss \& Schultka 2001, 2006; Philippe et al. 2004), driftwood bored by teredinids (Dietrich 1933a), and cuticles (Kahlert et al. 1999; Schultka in Heinrich et al. 2001). Palynomorphs (e.g. Jarzen 1981; Schrank 1999, 2005) and charophytes (Schudack 1999; Sames 2005, 2008) are also reported.

Age. Based on the existing biostratigraphical evidence, the age of the Tendaguru Formation ranges in the type area from the middle Oxfordian through the Tithonian (Lower to Upper Dinosaur Member) and from the Valanginian through Hauterivian or possibly Aptian (Rutitrigonia bornhardti-schwarzi Member) (e.g. Heinrich et al. 2001; Aberhan et al. 2002; Sames 2008).

\section{Members of the Tendaguru Formation}

\section{Lower Dinosaur Member}

Figures 2, 3, Table 2

Name. The name "Untere (erste) Saurierzone" (Lower Saurian Bed) was coined by Janensch (1914a) for the lowermost of the three dinosaur-bearing horizons of the Tendaguru Beds. Here, we formally emend this name, and other terms applied previously to this unit, to Lower Dinosaur Member (Table 2). Note that the term Lower Dinosaur Member was previously suggested by Schudack (1999) but the author failed to describe and define this member. The term refers to sauropod and theropod bones which were recovered from this unit.

Type section. Tendaguru Hill is regarded as the type locality of the Lower Dinosaur Member (Quennell et al. 1956). However, neither the GTE nor the BTE designated a type section for the Lower Saurian Bed. The GTTE has studied the Lower Dinosaur Member in the Tingutinguti stream section, at localities approximately $1.2 \mathrm{~km}$ southwest of Tendaguru Hill (Fig. 1; Tin 1, Tin $0 \mathrm{a}$, and Tin $0 \mathrm{~b}$ ). These beds cover only the upper part of the Lower Dinosaur Member. For this reason, we refrain from defining a type section of the Lower Dinosaur Member and the formal establishment of a complete type section has to await the discovery of more extended exposures.

Distribution. Exposures of the Lower Dinosaur Member are confined to the surroundings of Tendaguru Hill (Janensch 1914a). Outcrops are found along the western escarpment of the Tendaguru Plateau, where small tributaries of the Mbemkuru river have incised minor valleys such as the Kipande, Maimbwi, Tingutinguti, Dwanika, and Kindope creeks. Unfortunately, these exposures are largely overlain by Mbemkuru floodplain deposits and material derived from erosion of the stream section slopes. The generalised distribution of the Lower Dinosaur Member in the surroundings of Tendaguru Hill is illustrated by Hennig (1914a: geological map), Janensch (1914b: p. 45; 1925b: XVIII), and Aberhan et al. (2002: fig. 1).

Thickness. The thickness is difficult to determine owing to the lack of extended exposures. Janensch (1914a) reported more than $20 \mathrm{~m}$, Hennig (1937a) $15 \mathrm{~m}$ to $50 \mathrm{~m}$ for the entire thickness of the Lower Dinosaur Member in the Tendaguru area. The uneven underlying gneiss surface probably explains the variations in local thickness that are difficult to assess.

Lithofacies. Janensch (1914a) described the member as consisting of grey and reddish sandy marl exposed in the Tingutinguti and Dwanika stream sections. GTTE data from the Tingutinguti stream section showed that the upper portion of the Lower Dinosaur Member consists predominantly of light grey to green coloured, ripple cross-bedded, fine-grained sandstone and siltstone, with interbedded massive, clay-rich siltstone (Aberhan et al. 2002). Beds of massive, in part bioturbated, finegrained sandstone are intercalated, containing fragments of bivalves and fusain. The sediments are rich in feldspar and contain calcite; the clay mineralogy is dominated by smectite, with minor amounts of illite.

Boundaries. In the Tendaguru area, the Lower Dinosaur Member rests directly on Neoproterozoic gneiss (Janensch 1914a). According to Hennig (1914a), the contact with basement gneiss was observed at GTE site Ngwanya, located at the northwestern foot of the Namunda Plateau approximately $9 \mathrm{~km}$ southwest of Tendaguru Hill (for the geographic position of the site see Janensch 1914b: p. 50), but a detailed description of the contact was not given. Although the direct contact was not observed by the GTTE, the Lower Dinosaur Member is likely to be unconformably overlain by shallow marine deposits consisting of trough cross-bedded or massive, poorly sorted, medium- to coarse-grained sandstone of the Nerinella Member (Aberhan et al. 2002). Here, we define the boundary with the Nerinella Member by the first appearance of moderately to poorly sorted, medium- to coarse-grained sandstone.

Palaeontolgy. Mollusc assemblages from the upper part of the Lower Dinosaur Member (Tin 0a, Tin 1) are dominated by bivalves, notably juveniles of Meleagrinella radiata, Liostrea dubiensis, Nanogyra nana, and Eomiodon cutleri. Gastropods include Pseudomelania dietrichi, Cryptaulax sp., and Promathildia sp. (Aberhan et al. 2002). Serpulid worm tubes, benthic foraminifera, and fragments of echinoids and crinoids have also been found. Moreover, the ostracods Pirileberis madoensis and Cytherura sp. were identified (Sames 2008).

Poorly preserved fish remains recovered from Tin 0a do not permit precise taxonomic determinations (Arratia et al. 2002). The land vertebrate fauna is also poorly known due to the lack of outcrops. A few skeletal remains were assigned to Brachiosaurus brancai. Several 
isolated teeth of carnivorous dinosaurs were tentatively referred to 'Megalosaurus (?) ingens', 'Ceratosaurus (?) roechlingi' [= basal ceratosaur; Rauhut 2005], and 'Allosaurus (?) tendagurensis' [= basal tetanuran; Rauhut 2005] (Janensch 1925a, 1961a).

An impoverished palynoflora obtained from Tin 1 and Tin $0 \mathrm{a}$ contains chiefly conifer pollen grains of the Cheirolepidiaceae. Possible representatives of the Podocarpaceae and Araucariaceae have also been found along with pteridophytic spores (Aberhan et al. 2002). The mesoflora is dominated by cuticles of cheirolepidiaceans, while those of the Araucariaceae and ginkgoales are less common (Aberhan et al. 2002).

Age. The precise age of the Lower Dinosaur Member has not been established so far owing to the lack of adequate fossils. The occurrence of Pirileberis madoensis in Tin $0 \mathrm{a}$, together with ostracods recovered from the overlying Nerinella Member is supposed to indicate a middle Oxfordian or older age for the upper portion of the Lower Dinosaur Member (Sames 2008). Previous opinions had tentatively suggested an Oxfordian (Zwierzycki 1914; Krenkel 1925; Hennig 1937a) or even a Callovian age (Dietrich 1927a). In contrast, Quennell et al. (1956) and Aitken (1961) believed that the Lower Dinosaur Member is probably not older than middle or late Kimmeridgian.

\section{Nerinella Member}

Figures 2, 3, 4B-C, Table 2

Name. The strata here referred to as the Nerinella Member were originally described as "Untere Sandsteinzone (Nerineenzone)" (Nerinea Bed) by Janensch (1914a). They were provisionally named after the occurrence of nerineid gastropods (Janensch 1914a), which are common elements of the marine macroinvertebrate assemblages of the Tendaguru Formation. Cox (1965) referred to this unit as Nerinella Bed. He erected the new species Nerinella cutleri (Figs 5A-B), which is common in the Nerinella Bed at several localities in the Tendaguru area. However, N. cutleri is not an index fossil of this unit and also occurs in younger strata of the Indotrigonia africana Member. Here, we formally emend all terms applied previously to this unit to Nerinella Member (Table 2).

Type section. Tendaguru Hill is regarded as the type locality (Quennell et al. 1956), but neither the GTE nor the BTE designated a type section for the Nerinea Bed. Here, we formally establish a type section of the Nerinella Member defined from Tin 2 to Tin 5e in the Tingutinguti stream section (Fig. 3).

Distribution. Exposures of the Nerinella Member are confined to the surroundings of Tendaguru Hill and have not been definitely identified outside the Tendaguru region (Quennell et al. 1956; Aitken 1961). The generalised distribution of the Nerinella Member in the
Tendaguru area is illustrated, for instance, by Hennig (1914a: geological map) and Aberhan et al. (2002: fig. 1). Mapping by Hennig (1914a) showed that it stretches along the western escarpment of the Tendaguru Plateau, mainly between the Kindope stream section to the north and the Kipande stream section to the south. Outcrops are reported from the Kindope and Tingutinguti stream sections (Janensch \& Hennig 1914) as well as from the Bolachikombe stream section south of Tendaguru Hill (see inlay of Fig. 1; Dietrich 1933a). Continuous exposures of the Nerinella Member can be observed in the Tingutinguti stream section south of Tendaguru Hill (Aberhan et al. 2002).

Thickness. Janensch (1914a) reported a thickness of $25 \mathrm{~m}$ for the Nerinella Member in the Tendaguru area. Hennig (1937a) gave the following thickness measurements: ca. $45 \mathrm{~m}$ (Kipande path), 15-20 m (Tingutinguti stream section), ca. $25 \mathrm{~m}$ (Nambiranj path), 30-35 m (Dwanika stream section), and 15-20 m (Kindope stream section). Based on data mainly obtained in the Tingutinguti stream section, Aberhan et al. (2002) reported a thickness of approximately $20 \mathrm{~m}$ for the Nerinella Member at the type section.

Lithofacies. Originally, the Nerinella Member was described as consisting of friable, fine- to mediumgrained, limey, yellowish sandstone (ca. 6-7 m) which is overlain by fine- to medium-grained, limey, grey sandstone $(11-13 \mathrm{~m})$, followed by friable, fine-grained, yellowish sandstone (6-7 m) (Janensch 1914a). This description was rendered more precisely by the GTTE. According to Aberhan et al. (2002), the member is mainly characterised by (1) trough cross-bedded or massive, poorly sorted, medium- to coarse-grained sandstone; (2) massive to indistinctly cross-bedded, fine- to medium-grained sandstone containing occasionally rich assemblages of marine invertebrates; (3) stacked sequences of chiefly trough cross-bedded, fineto medium-grained sandstone; and (4) well sorted, horizontally bedded to low-angle cross-bedded sandstone and isolated swaley cross-bedded sandstone. The sandstone is generally rich in feldspar, but variable in respect of the content of fossils, calcite cement, heavy minerals and micas, as well as in sorting and sedimentary structures.

The basal part of the Nerinella Member is built up mainly by trough cross-bedded to massive, moderately to poorly sorted, medium- to coarse-grained, in part pebbly, grey to yellow coloured, calcite-cemented, siliciclastic sandstone. The sandstone is rich in bioclasts, predominantly bivalves, foraminifera, and echinoderms, but also in lithoclasts. It forms crude fining-upward sequences. Dip directions of cross-bedding foresets indicate a variably directed sediment transport.

The basal sandstone is overlain by horizontally bedded to low-angle cross-bedded, in part ripple crossbedded, mostly well sorted, fine- to medium-grained, grey to brown coloured, calcite-containing, siliciclastic sandstone. In comparison to the basal part of the Neri- 


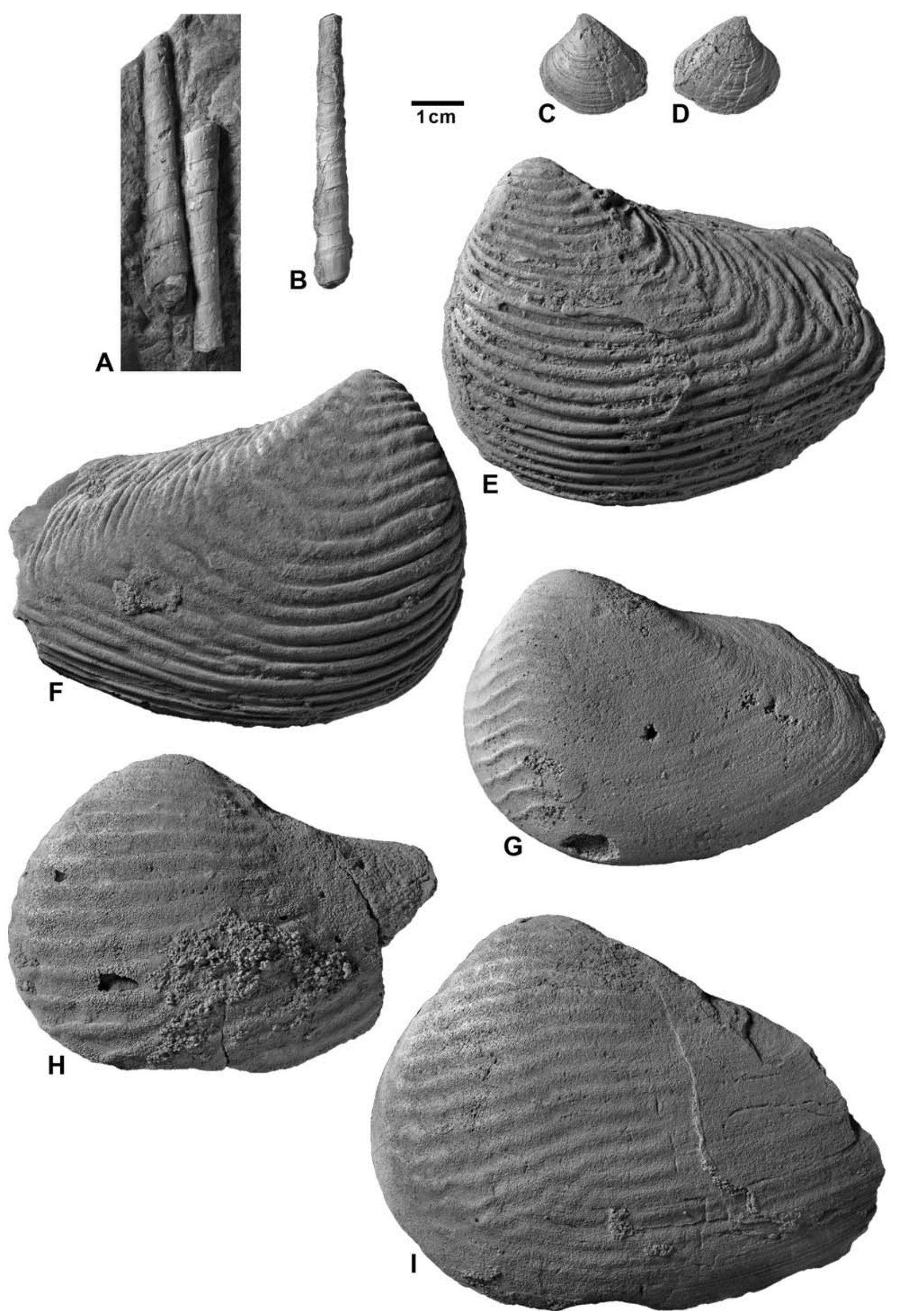


nella Member, these beds contain less bioclasts, but are richer in mica. Several layers with heavy mineral concentrations are also present.

The basal part is overlain by mostly trough crossbedded, fine- to coarse-grained, moderately to well sorted, yellow to brown coloured sandstone. Some of these sandstone layers contain abundant bioclasts, mainly echinoderms, bivalves, and some foraminifera as well as coalified woody plant fragments, whereas others contain only few bioclasts, but increased amounts of mica and heavy minerals. The calcite content is generally low. Transport directions are highly variable, with NE, E, and $\mathrm{W}$ directions being most prominent.

The uppermost part of the Nerinella Member is formed by dominantly trough cross-bedded, in part bioturbated, poorly to well sorted, coarse- to fine-grained, yellow to brown coloured, calcite-containing, siliciclastic sandstone. Bioclasts are limited to scattered bivalve remains, whereas in some beds heavy mineral-rich layers are present. The sandstone forms thin fining-upward sequences that start with an erosive boundary, overlain by coarse-grained pebbly sandstone grading upward into trough cross-bedded and finally into ripple cross-bedded fine-grained sandstone. Sediment transport directions are again variable, and mainly oriented to the NE, E, and SW.

Boundaries. The Nerinella Member is underlain by the Lower Dinosaur Member and overlain conformably by the Middle Dinosaur Member. The lower boundary is defined by a clear break in grain-size of the sediments and the first appearance of moderately to poorly sorted, medium- to coarse-grained sandstone. We define the upper boundary to the Middle Dinosaur Member with the last appearance of some decimeter thick, fine- to medium-grained, cross-bedded sandstone.

Palaeontolgy. Common macroinvertebrates of the basal parts of the Nerinella Member (e.g. Tin 2, Tin 3/base, Tin 3b) are the bivalves Protocardia schencki and Grammatodon irritans that are associated with limids and pectinids (Aberhan et al. 2002), while gastropods are generally less common. However, Hennig (1937a) reported a local mass accumulation of gastropods ("Schneckennest") of the Nerinea Bed associated with 'Perisphinctes sparsiplicatus' [= Pachyplanulites? sp.; G. Schweigert, personal communication 2008] from a small stream section located between the Tingutinguti and Maimbwi stream section. Janensch \& Hennig (1914) mentioned only three localities that have produced invertebrates from the Nerinea Bed: Kindope (approximately $5 \mathrm{~km}$ north-northwest of Tendaguru Hill) and GTE invertebrate sites 3 (about $3 \mathrm{~km}$ northwest of Tendaguru Hill, path to Nanundo) and 14 and 14a (Tingutinguti stream section). Dietrich's (1914, 1925a, 1933a) and Cox' (1965) descriptions of the gastropods and bivalves of the Nerinea Bed include, for instance, 'Nerinella credneri' [= Nerinella cutleri $]$, 'Patella' [= Scurriopsis (Dietrichiella)] kindopensis, Lissochilus stremmei, Stegoconcha gmuelleri, Arcomytilus subpectinatus, 'Astarte' [= Herzogina $]$ recki, Rutitrigonia dietrichi, and many others. Cephalopods are rare elements (e.g. Nautilus sattleri, Haploceras [= Metahaploceras sp.; G. Schweigert, personal communication 2008], 'Perisphinctes sparsiplicatus' [= Pachyplanulites? sp.; G. Schweigert, personal communication 2008], Perisphinctes staffi; Zwierzycki 1914; Dietrich 1925a; Spath 1928-1933; Arkell 1956; Torquatisphinctes cf. torquatus, Taramelliceras sp. ex gr. kiderleni; Heinrich et al. 2001). The calcareous microfauna from Tin 2a includes ostracods (e.g. Majungaella oxfordiana, Cytherella disjuncta, Cytherella umbilica, Fastigatocythere sp.; Sames 2008), and undetermined benthic foraminifera (Aberhan et al. 2002).

Calcareous concretions obtained from bioturbated sandstone deposits in the lower part of the Nerinella Member (Tin 3d) have yielded a rich macroinvertebrate assemblage dominated by bivalves (see Aberhan et al. 2002: fig. 3). Ostracods (e.g. Cytherella disjuncta, Cytherella umbilica?, Galliaecytheridea manyuliensis, Mandelstamia sp. 2, Bairdia sp. and Majungaella sp. 1; Sames 2008) and benthic foraminifera have also been recovered from the lower part of the Nerinella Member. Moreover, it has produced a Rigaudella aemula-Chlamydophorella wallala assemblage of palynomorphs (Schrank 2005). GTTE bed Tin $3 \mathrm{~d}$ has also produced conifer woods (as fusain) which were identified as Primopodocarpoxylon podocarpoides (Süss \& Schultka 2006).

Age. Based on dinoflagellate cysts, the Nerinella Member exposed in the Tingutinguti stream section (Tin 2Tin 4h) ranges from Oxfordian to Kimmeridgian in age (Schrank 2005). Similarly, Sames (2008) suggested an age range from at least the middle Oxfordian to the

Figure 5. Characteristic Late Jurassic and Early Cretaceous invertebrates of the Tendaguru Formation; A-B. Nerinella cutleri Cox; Nerinella Member, Tendaguru, Tingutinguti streambed, GTE site 14; A. MB.Ga.3847.1; B. MB.Ga.1104; C-D. Eomiodon cutleri Cox; Upper Dinosaur Member, Tendaguru, GTE site G; MB.M.1645.4; C. Left valve view; D. Right valve view; E-F. Indotrigonia africana Aitken; Indotrigonia africana Member, Tendaguru, Tingutinguti streambed, GTE site 1; E. Left valve view; MB.M.1620; F. Right valve view; MB.M.1636; G. Rutitrigonia schwarzi (Müller), left valve view; Rutitrigonia bornhardti-schwarzi Member, Likonde-Kitale; MB.M.1779; H-I. Rutitrigonia bornhardti (Müller), left valve view; Rutitrigonia bornhardti-schwarzi Member; H. West of Ngomanji between Niongala and Mtapaia; MB.M.1783.2; I. Ntandi; MB.M.5912.1. All specimens are figured in natural size. They have been coated with ammonium chloride and are housed at the Museum für Naturkunde Berlin (inventory numbers with the prefix $\mathrm{MB}$ ). 
Kimmeridgian for ostracod assemblages recovered from the lower portion of the Nerinella Member (Tin 2a, Tin 3b, Tin 3d). On the basis of ammonoids, previous studies assigned an Oxfordian (Zwierzycki 1914; see also Hennig 1937a), Sequanian (late Oxfordian) (Dietrich 1933b), Oxfordian (?)-late Kimmeridgian (Aberhan et al. 2002), early to middle Kimmeridgian (Dietrich 1925a), and late Kimmeridgian age (Arkell 1956; Heinrich et al. 2001). A definite age determination, however, is not possible with the available ammonoids, although a late early Kimmeridgian (Divisum Zone) age appears most likely (G. Schweigert, personal communication 2008). Therefore, we retain a relatively wide age range herein and tentatively suggest an Oxfordian to Kimmeridgian age range for the Nerinella Member.

\section{Middle Dinosaur Member}

Figures 2, 3, 4D, Table 2

Name. The name "Mittlere (zweite) Saurierzone" (Middle Saurian Bed) was coined by Janensch (1914a) for the middle of the three dinosaur-bearing units of the Tendaguru Beds. Here, we formally emend this name and other terms, applied previously to this unit, to Middle Dinosaur Member (Table 2). Note that the term Middle Dinosaur Member was previously suggested by Schudack (1999) but the author did not describe and define this member. The name refers to the rich assemblages of well preserved sauropod, ornithopod, and theropod bones.

Type section. Tendaguru Hill is regarded as the type locality (Quennell et al. 1956). Neither the GTE nor the BTE designated a type section for the Middle Saurian Bed. Here, we formally establish the type section of the Middle Dinosaur Member in the Tingutinguti stream section, defined from Tin 6 a to Tin $7 \mathrm{~m}$ (Fig. 3).

Distribution. Deposits of the Middle Dinosaur Member have been recognised over large parts of the hinterland of the towns of Kilwa and Lindi. Its generalised distribution in the surroundings of Tendaguru Hill and adjacent areas was illustrated in a geological map (scale $1: 300.000)$ by Hennig (1914a). Based on further data of the GTE (Janensch 1914b) and new data of the GTTE, the distribution of the member in the immediate surroundings of Tendaguru Hill was presented in a map by Aberhan et al. (2002: fig. 1). Accordingly, the member is mainly known from outcrops along the western escarpment of the Tendaguru Plateau and, for instance, from exposures at Mtapaia (GTE sites Aa, XX) about $10 \mathrm{~km}$ north of Tendaguru Hill. Farther to the west, deposits are restricted to an isolated outlier between Nakihu and Maonga approximately 11 to $12 \mathrm{~km}$ northwest of Tendaguru Hill (fig. 1) (Hennig 1914a). More extensive outcrops of the Middle Dinosaur Member are also present in the valley of the Mtshinyiri river, a tributary of Mbemkuru river, and southeast of Minyoka where it crops out extensively in two belts along the slopes of the Mbemkuru stream valley (fig. 1) (Hennig 1914a).
The westernmost outcrop of the member is probably GTE site Oa at Obolello, located approximately $15 \mathrm{~km}$ southwest of Tendaguru Hill. At this locality two dinosaur beds were exposed in superposition, of which one is likely identical with the Middle Dinosaur Member (Janensch 1914b). The member is also present at GTE site $\mathrm{S}$ in the Kitukituki stream section, about $1.0 \mathrm{~km}$ south-southwest of Tendaguru Hill, that has produced two skeletons of Brachiosaurus brancai, among them the famous Berlin specimen (Janensch 1950b).

Thickness. Janensch (1914a) reported a thickness of approximately $15 \mathrm{~m}$ for the Middle Dinosaur Member in the type area. Thickness data by Hennig (1937a) are as follows: ca. $15-20 \mathrm{~m}$ (Kipande path), $10 \mathrm{~m}$ (Tingutinguti stream section), ca. $10 \mathrm{~m}$ (Nambiranji path), 15-20 m (Dwanika stream section), and $30 \mathrm{~m}$ (Kindope stream section). The GTTE measured a thickness of $13 \mathrm{~m}$ for the Middle Dinosaur Member in the Tingutinguti stream section (Aberhan et al. 2002).

Lithofacies. Janensch (1914a) defined the Middle Saurian Bed as alternating layers of grey and red, sandy marl with dinosaur bones and an argillaceous bed at the base $(12 \mathrm{~m})$, overlain by red sandy marl $(3 \mathrm{~m})$. Field work of the GTTE has shown that the lower part of the Middle Dinosaur Member is mainly built up by ripple cross-bedded, fine-grained siliciclastic sandstone and siltstone, and massive to crudely bedded silt- and claystone (Aberhan et al. 2002). The sandstone and siltstone is mainly light grey coloured, whereas the clay-rich deposits are dark grey or reddish-brown. The sediments contain very variable amounts of calcite as well as sporadic dolomite. The clay mineralogy is dominated by smectite and illite, containing traces of kaolinite as well. Fossils such as bivalves and gastropods are most abundant in the basal part of the member.

The basal part consists of fining-upward sequences that are some decimetres thick. They are composed of ripple cross-bedded to ripple cross-laminated, finegrained sand- and siltstone that grades upward into massive clayey siltstone with abundant bivalve and gastropod remains. The calcite content is highly variable; dolomite-rich beds are missing, in contrast to the upper part of the member. Ripple cross-bedded sandstone beds occasionally contain heavy mineral layers. In the upper part of the fining-upward sequences, some sandy to silty micritic limestone beds occur.

In the upper part of the Middle Dinosaur Member, sandy to silty and partly peloidal micrite horizons are intercalated into the prevalent siltstone and fine-grained sandstone. Lithoclasts consisting of sandy to silty micrite are also present in adjacent sandstone beds. The calcite content is variable and, in several beds, dolomite is present. Two bone beds at GTE site Ig (WJ) represent channel lag deposits containing dinosaur bones, mud clasts, and reworked caliche nodules.

Boundaries. The lower boundary of the Middle Dinosaur Member to the Nerinella Member is defined as 
the first occurrence of ripple cross-laminated, finegrained sandstone and siltstone on top of cross-bedded, fine- to medium-grained sandstone. It is very likely a conformable, gradual contact without a major shift in facies, and reflects a more or less continuous change from upper shoreface to shallow lagoonal sediments. In contrast, the upper boundary is unconformable to the Indotrigonia africana Member. It is marked by a conspicuous break in grain-size that corresponds to a considerable environmental change, with ripple cross-laminated siltstone and fine-grained sandstone erosively overlain by trough cross-bedded, coarse-grained pebbly sandstone.

Palaeontolgy. Vertebrates of particular significance include fishes (e.g. Lepidotes sp., unidentified selachians and teleosts; Arratia et al. 2002; Hennig 1914b), as yet unidentified amphibians [Lissamphibia (Salientia?) indet.; Aberhan et al. 2002; Heinrich 2003], a paramacellododid lizard (Broschinski 1999), pterosaurs (e.g. Tendaguripterus recki; Unwin \& Heinrich 1999), crocodiles (e.g. Bernissartia sp.; Heinrich et al. 2001; Aberhan et al. 2002), dinosaurs (e.g. Elaphrosaurus bamber$g i$, 'Coelurosaurier $\mathrm{B}$ and $\mathrm{C}$ ' [= abelisauroid; Rauhut 2005], 'Allosaurus (?) tendagurensis' [= basal tetanuran; Rauhut 2005], 'Ceratosaurus (?) roechlingi' [= basal ceratosaur; Rauhut 2005], 'Labrosaurus (?) stechowi', 'Megalosaurus (?) ingens', Dicraeosaurus hansemanni, Brachiosaurus brancai, Kentrosaurus aethiopicus, Dysalotosaurus lettowvorbecki (e.g. Janensch 1914c, 1920, 1925a, 1929a, 1929b, 1955, 1961a; Hennig 1925; Galton 1981; Rauhut 2003, 2005), and mammals (Allostaffia aenigmatica, Tendagurodon janenschi, Tendagurutherium dietrichi, and as yet unidentified symmetrodonts; Heinrich 1998, 1999b, 2001, 2003).

Invertebrate fossils have been found throughout large parts of the Middle Dinosaur Member. At its base, as identified at GTE site 19 within the Bolachikombe stream section approximately $3 \mathrm{~km}$ south of Tendaguru Hill (Fig. 1) (Hennig 1914b), massive, limey sandstone deposits were found just below skeletal remains of Brachiosaurus brancai, among them a bone which was overgrown with oysters (Janensch, GTE field catalogue: p. 76). These sandstone beds yielded 'Cyrena' [=Eomiodon], 'Mytilus' [= Falcimytilus], Pseudomelania, 'Nerita', and other invertebrates (Hennig 1914b; Dietrich 1933a). Similarly, at the Tingutinguti stream section, the basal part of the Middle Dinosaur Member (Tin 6, Tin 7b) yielded a macrobenthic mollusc assemblage that is strongly dominated by the bivalve Eomiodon cutleri (Aberhan et al. 2002). Mytilid bivalves and gastropods (e.g. Promathildia sp., Pseudomelania dietrichi) are far less common. About $300 \mathrm{~m}$ west of Tendaguru Hill, the lowermost beds of the Middle Dinosaur Member and the contact with the underlying Nerinella Member were exposed at GTE site $p$ that has produced an articulated series of Brachiosaurus brancai caudal vertebrae (Janensch, GTE field catalogue: p. 56), again associated with 'Cyrena' [=Eomiodon], and pseudomelanid gastropods together with 'Trigonia' and crinoids (Hennig 1914b).

In the remaining part of the type section, from Tin $7 \mathrm{c}$ to Tin 71, macroinvertebrates are rare, and in addition to the previously mentioned mollusc taxa small specimens of the eurytopic oysters Liostrea and Nanogyra occur (Aberhan et al. 2002). The uppermost strata of the Middle Dinosaur Member were exposed at GTE site Aa near Mtapaia (Hennig 1914a). They consist of poorly lithified, sandy marl (Dietrich 1933a) that have yielded skeletal remains of Brachiosaurus brancai, among them a humerus overgrown by oysters (Janensch GTE field catalogue: p. 140), and invertebrates such as Thracia incerta, Pleuromya tellina, 'Cyrena'sp. [= Eomiodon], Protocardia schencki, 'Trigonia' [=Indotrigonia] dietrichi, 'Modiola' [= Inoperna $]$ perplicata, 'Pseudomonotis tendagurensis' [= Meleagrinella radiata], and Perisphinctes sp. (Hennig 1914b).

Ostracods from GTE site Aa are referred to Trapezoidella sp. and Paracypris sp. (Schudack \& Schudack 2002). Dietrich (1933a) considered these deposits as brackish transitional beds that connected the Middle Dinosaur Member with the overlying Indotrigonia africana Member. Owing to their fine-grained nature, we include these transitional beds in the Middle Dinosaur Member. Ostracods have also been recovered recently from the lower part the type section (Tin 7a, Tin 7b, Tin 7d), notably Bythocypris sp., Cytheropteron sp., Cetacella sp., Darwinula sp., Trapezoidella sp., and Cypridea sp. 1 (Sames 2008). Higher up (Tin 7g, Tin 7i), Darwinula? sp., Cypridea sp. 2 and sp. 3, and Mantelliana sp. were recognised (Sames 2008). Moreover, the bone bed WJ at GTE site Ig (= GTE site dy; Janensch 1955) has yielded the ostracods Mandelstamia sp. and Cetacella sp. (Schudack \& Schudack 2002). In addition, Trapeziodella sp. B, Mandelstamia sp., Cypridea sp., Rhinocypris sp., and Darwinula sp. and others were reported from the Middle Dinosaur Member of the Kitukituki stream section by Schudack \& Schudack (2002).

Only a few flagellate dinocysts have been recovered from the Middle Dinosaur Member, chiefly from the lower (Tin 6a, Tin 7b) and middle part of the succession (Tin 7f/1, Tin 7f/2) (Schrank 2005). They are representatives of the Endoscrinium attadalense-Ctenidodinium sellwoodi group assemblage (Schrank 2005). Charophytes are known from GTE site Ig (WJ) (Mesochara canellata, Mesochara harrisi, Aclistochara cf. bransoni), from the Cyrena Marls (Mesochara harrisi), from deposits exposed in the Kitukituki stream section (Mesochara harrisi, Mesochara canellata, Aclistochara cf. minor) (Schudack 1999) and from Tin 7d (Mesochara sp.; Sames 2008). Freshwater algae (Ovoidites) have also been found in Tin 6 and Tin $7 f$ (Aberhan et al. 2002).

Age. The age of the Middle Dinosaur Member was tentatively identified as late Kimmeridgian or Tithonian by Quennell et al. (1956). Recent work on dinoflagellate cysts suggests that the Endoscrinium attadalense- 
Ctenidodinium sellwoodi group assemblage from the Middle Dinosaur Member is likely late Kimmeridgian (Schrank 2005). This dating is consistent with the palaeontological age assessments of Schudack \& Schudack (2002). This led us to tentatively assign a late Kimmeridgian age to the Middle Dinosaur Member.

\section{Indotrigonia africana Member}

Figures 2, 3, 4E, Table 2

Name. This member is named after the bivalve species Indotrigonia africana (Figs 5E-F). Lange (1914), Dietrich (1933a), and Cox (1952) accepted that Trigonia smeei from the Upper Jurassic of the Tendaguru area and adjacent regions was taxonomically identical to Trigonia smeei from the Argovian of Kachchh, western India. However, data subsequently published by Aitken (1961) indicated that the Tendaguru specimens referred to Trigonia smeei differ from the Indian smeei. They belong to a distinct species which was described as Trigonia (Indotrigonia) africana by Aitken (1961). We therefore change the name "Mittlere Sandsteinzone mit Trigonia smeei" (Janensch 1914a) (Trigonia smeei Bed) and other terms applied previously to this unit to Indotrigonia africana Member (Table 2). The term Trigonia smeei Bed was coined for the middle of the three marine horizons of the Tendaguru Beds (Hennig 1914a; Janensch 1914a) and applied for strata considered to be equivalent to those deposits which were previously described by Fraas (1908) as "Trigonienschichten mit Trigonia beyschlagi" (Hennig 1914a).

Type section. Tendaguru Hill is regarded as the type locality (Quennell et al. 1956). Janensch's (1914a) description of the Trigonia smeei Bed is based on exposures in the Tingutinguti stream section. Neither the GTE nor the BTE designated a type section. Here, we formally establish a type section for the Indotrigonia africana Member in the Tingutinguti stream section, defined from beds Tin 8 to Tin 9w (Fig. 3).

Distribution. The generalised distribution of the Indotrigonia africana Member in the surroundings of Tendaguru Hill and adjacent areas was illustrated in a geological map (scale $1: 300,000)$ by Hennig (1914a). The distribution of the member in the immediate surroundings of Tendaguru Hill is shown by Aberhan et al. (2002: fig. 1). The member is mainly exposed in stream sections of the tributaries of the Mbemkuru river, such as the Mtapaia, Mtshinyiri and Marihi creeks, in the Mbemkuru stream valley southeast of Minyoka, and in the Kikundi stream section (Hennig 1914a, 1937a). Farther to the north, Hennig (1914a) had mapped strata with Trigonia smeei in the Mahokondo area. However, Quennell et al. (1956) and Aitken (1961) have shown that Trigonia smeei recovered from the lower part of the so-called smeei-Oolite and the "Haupt-smeei-Zone" of the Mandawa-Mahokondo area is distinct from that of the Indotrigonia africana Member in the Tendaguru area. It was described as Indotrigonia mandawae (Aitken 1961). Consequently, the correlation is lapsed (Aitken 1961). The Indotrigonia africana Member is welldeveloped along the western escarpment of the Tendaguru Plateau as well as south of Tendaguru Hill in the Tingutinguti and Maimbwi stream sections.

Thickness. At Tendaguru Hill the Indotrigonia africana Member is about $20 \mathrm{~m}$ thick (Janensch 1914a), with gradual thickening to the northeast to about $30 \mathrm{~m}$ in the Mtapaia stream section and a more marked thickening towards the northeast to about $50 \mathrm{~m}$ in the Mtshinyiri stream section at Matapua (Hennig 1937a). In addition, Hennig (1937a) gave the following thickness measurements: ca. $20 \mathrm{~m}$ (Kipande path), ca. $30 \mathrm{~m}$ (Tingutinguti stream section), ca. $17 \mathrm{~m}$ (Nambiranji path), 20-25 m (Dwanika stream section), and $30 \mathrm{~m}$ (Kindope stream section) (Fig. 1). Based on data mainly obtained in the Tingutinguti stream section, Aberhan et al. (2002) reported a thickness of approximately $20 \mathrm{~m}$ for the Indotrigonia africana Member.

Lithofacies. The deposits of the Indotrigonia africana Member were described as friable, soft, yellow and grey sandstone with intercalations of massive calcareous, fine- to coarse-grained, sometimes conglomeratic sandstone horizons (Janensch 1914a). Data of the GTTE have shown that the deposits in the Tendaguru area mainly consist of brown to grey, calcite-cemented, bioclast-rich sandstone, several conglomerate beds as well as of some thin clay- and siltstone layers and sandy limestone (Aberhan et al. 2002; Bussert \& Aberhan 2004). In the upper part of the succession the sandstone interfingers with oolitic limestone northeast of Tendaguru Hill (Aberhan et al. 2002). Similar to the Nerinella Member, the sandstone of the Indotrigonia africana Member is uniformly rich in feldspars, whereas its calcite content is highly variable.

The Indotrigonia africana Member can be subdivided into three parts. The basal part consists of stacked sequences of trough cross-bedded, partly low angle or tabular cross-bedded, moderately to poorly sorted, coarse- to medium-grained, pebbly sandstone. This sandstone frequently forms thin fining-upward sequences which start with a basal erosion surface. Palaeocurrent directions, derived from dip directions of the cross-bedding foresets, are variable. Bioclasts are represented mostly by fragments of bivalves, and by some echinoderms. In several layers, concentrations of heavy minerals occur.

The middle part is mainly built up by cross-bedded, fine- to medium-grained sandstone, and by ripple crossbedded, in part flaser, lenticular or parallel bedded, finegrained sandstone, siltstone, and minor claystone. At several levels, beds of coarse-grained pebbly sandstone or conglomerates, mostly $10-25 \mathrm{~cm}$ thick, are intercalated. These beds start with a basal erosion surface and display wave ripple as well as swaley and hummocky cross-bedding structures. They contain abundant bioclasts, predominantly bivalves, as well as concentrations of heavy minerals and lithoclasts. 
The upper part of the member consists mostly of trough cross-bedded, moderately to poorly sorted, coarse- to medium-grained, pebbly sandstone, some of which form fining-upward sequences. Although bioclasts such as bivalves are present, they are rarer when compared to the middle part of the member.

Fossils such as bivalves, gastropods, corals, echinoderms, and foraminifera are present in all parts of the member, but are most abundant in the middle part.

Boundaries. An unconformable, sharp and erosive contact, marked by an abrupt increase in grain-size from siltstone and fine-grained sandstone of the Middle Dinosaur Member to trough-cross-bedded, coarse-grained sandstone and the occurrence of heavy-mineral concentrations represent the lower boundary of the Indotrigonia africana Member. The lower boundary clearly reflects substantial erosion as well as a major environmental change. The upper boundary to the Upper Dinosaur Member is defined by the topmost appearance of medium- to fine-grained, cross-bedded sandstone beds, which are conformably overlain by cross-laminated finegrained sandstone of the Upper Dinosaur Member. The lower boundary is best exposed in the Dwanika and the upper boundary in the Tingutinguti stream section.

Palaeontolgy. The Indotrigonia africana Member contains a diverse marine assemblage of macroinvertebrates, including corals (e.g. Astrocoenia bernensis and 'Latimaeandraraea' [= Meandrophyllia] oolitotithonica; Dietrich 1926), bivalves (e.g. 'Epihippopodium' [= Hippopodium quenstedti, 'Astarte' [= Herzogina recki, 'Astarte' [=Seebachia $\quad k r e n k e l i, \quad$ 'Cardium (Tendagurium)' [=Integricardium $]$ propebanneianum, Lithophaga suboblonga, Chlamys curvivarians, Protocardia schencki, Pseudomonotis tendagurensis [= Meleagrinella radiata], Indotrigonia dietrichi, Indotrigonia africana, and many others (Dietrich 1933a; Quennell et al. 1956; Aitken 1961; Cox 1965), gastropods (e.g. 'Nerinea' [= Cossmannea $]$ hennigi, Nerinella credneri $[=N$. cutleri], Pleurotomaria aff. jurensis, and Pseudomelania dietrichi; Dietrich 1914, 1933a; Cox 1965), cephalopods (e.g. Subdichotomoceras cf. sparsiplicatum, Hildoglochiceras kobelli, Holcophylloceras mesolcum, Haploceras elimatum, 'Craspedites' [= Procraspedites] africanus, Nautilus dorsatus var. sattleri, Belemnites aff. tanganensis; Zwierzycki 1914; Dietrich 1933a; Arkell 1956; Quennell et al. 1956), brachiopods (Terebratula carteroniana, Terebratula matapuana, Rhynchonella expressa; Lange 1914; Hennig 1937a; Quennell et al. 1956), echinoderms (e.g. Cidaris glandifera, Apiocrinus sp.; Dietrich 1933a; Hennig 1937a; Sieverts-Doreck 1939), and arthropods (Protaxius sp.; Beurlen 1933). More recently recovered macroinvertebrate assemblages of the Indotrigonia africana Member are summarised by Aberhan et al. (2002).

The microfauna includes textulariid, lenticuline, and nodosariid foraminifera and ostracods (Zils et al. 1995). More recently, GTTE beds Tin $9 j$, Tin $9 \mathrm{p} / 3$, Tin $9 p / 5$, Tin 9qb, and Tin 9r have yielded ostracod assemblages, covering the middle part of the member. The following taxonomical identifications have been made (Sames 2008): Cytherella cf. obscura?, Bythocypris sp.?, Majungaella sp. 2, Pirileberis sp. 1, sp. 2 and sp. 3, Cypridea sp. 4, Pleurocythere sp., Ilyocypris sp., Procytherura sp., Mandawacythere striata?, and Cytherella sp. 2.

Charophyta (Clavatoroidea indet.) are reported from Tin 9p/5 (Sames 2008). Schrank (2005) recorded a Dingodinium jurassicum-Kilwacysta assemblage, consisting of about 50 short- and long-ranging dinocyst species. They include Microdinium avocetianum (Tin 9f2), Pareodina robusta (Tin 9f2, Tin 912), Kilwacysta semiseptata (Tin 9g to Tin 912), Kilwacysta multiramosa (Tin 9j2, Tin 9p2), and Tubotuberella apatela (Tin 9j1 to Tin 9o1). Some of the dinoflagellate cyst taxa are associated with acritarchs and freshwater algae (Schrank 2005). Msaky (2007) reported the dinoflagellates Wanaea tendagurensis, Dingodinium swanense, Prolixosphaeridium mixtispinosum, Pareodinia antennata, and Komewuia glabra.

GTTE bed Tin 9h, located in the lower portion of the Indotrigonia africana Member, has yielded the richest and most diverse conifer assemblage of the Tendaguru Formation (Süss \& Schultka 2006), including Primopodocarpoxylon circoporoides, Semipodocarpoxylon compactum, Glyptostroboxylon janenschii, Tetraclinoxylon antiquum, and Paratetraclinoxylon tendagurense. Higher up in the section, specimens of Taxodioxylon compressum (Tin 9p) and Podocarpoxylon jurassicum, Podocarpoxylon microtracheidale, and Widdringtonioxylon tanzaniense (all Tin 9q) were found (Süss \& Schultka 2006).

Age. Previously, the Indotrigonia africana Member was dated as middle to late Kimmeridgian (Hennig 1937a, 1937b), late Kimmeridgian to early Tithonian (Dietrich 1925a, 1926), late Kimmeridgian to Tithonian (Zwierzycki 1914; Lull 1915; Behrendt 1918; Aitken 1961), Kimmeridgian to Tithonian (Schrank 1999), and Tithonian (Lange 1914; Schrank 2005). In contrast, Spath (1928-1933) assigned it, along with the Nerinella Member and the two upper dinosaur-bearing members, to the Portlandian (see also Hennig 1937a; Aitken 1961: tab. 2).

More recently, evaluation of the stratigraphical ranges of dinocyst taxa strongly suggests "a Tithonian, probably Late Tithonian age for the Trigonia smeei Bed, at least up to level Tin 9o4" (Schrank 2005: p. 78). Higher up, Barbatacysta creberbarbata, Barbatacysta capitata, and Dingodinium jurassicum (all known from Tin 9p2) "suggest a Late Jurassic, rather than an Early Cretaceous age" (Schrank 2005: p. 78). The short-ranging dinoflagellate Wanaea tendagurensis, reported from the Indotrigonia africana Member together with Dingodinium swanense, Prolixosphaeridinium mixtispinosum, and Pareodinia antennata, is assumed to be an index fossil for the Kimmeridgian of Tanzania (Msaky 2007). Another dinocyst taxon, Komewuia glabra, is known from the late Kimmeridgian to Tithonian of Madagascar (Chen 1982) and the Kimmer- 
idgian to Tithonian of Kenya (Jiang et al. 1992). Consequently, the co-occurrence of Wanaea tendagurensis and Komewuia glabra could indicate a Kimmeridgian age for the Indotrigonia africana Member. However, a Tithonian age appears more likely, because the underlying Middle Dinosaur Member is probably late Kimmeridgian in age. This view is corroborated by the presence of the ammonoids Procraspedites africanus and several species of Hildoglochiceras, which indicate an early Tithonian age (G. Schweigert, personal communication 2008). Overall, the existing microfloral record suggests a Late Jurassic rather than an Early Cretaceous age, as suggested previously (e.g. Dietrich 1925a, 1926, 1933a; Hennig 1937a; Quennell et al. 1956). In contrast, Sames (2008) tentatively placed the JurassicCretaceous boundary a short distance below the strata exposed at Tin $9 \mathrm{p} / 5$ into the Indotrigonia africana Member.

\section{Upper Dinosaur Member}

Figures 2, 3, 4F, Table 2

Name. The name "Oberste (dritte) Saurierzone" (Upper Saurian Bed) was coined by Janensch (1914a) for the uppermost of the three dinosaur-bearing horizons of the Tendaguru Beds. Here, we formally emend the name and other terms applied previously to this unit to Upper Dinosaur Member (Table 2). Note that the term Upper Dinosaur Member was previously suggested by Schudack (1999) but the author failed to describe and define this member. The name refers to the assemblages of sauropod, ornithopod, and theropod bones.

Type section. Tendaguru Hill is regarded as the type locality (Quennell et al. 1956). Neither the GTE nor the BTE designated a type section. Here, we formally establish a type section of the Upper Dinosaur Member defined from subsections Tin S0, Tin 10a to Tin 10e, Dwa 1 to Dwa 7, Tin 11a to Tin 11d (Fig. 3; Table 3).

Distribution. The Upper Dinosaur Member is the most widespread member of the Tendaguru Formation. According to the geological map of Hennig (1914a), scattered outcrops extend from the eastern shore of Lake Lutambo, about $30 \mathrm{~km}$ west of the town of Lindi, for ca. $145 \mathrm{~km}$ in a northwestern direction to the banks of Matandu river at Mitole, approximately $36 \mathrm{~km}$ west of Kilwa-Kivinje (Fig. 1). The best studied area with exposures of the Upper Dinosaur Member is the Tendaguru region.

Hennig (1914a, 1937a) suggested that the Upper Dinosaur Member of the Tendaguru area passes eastwards into marine calcareous ooid-bearing strata. Oolitic limestone (smeei Oolite), developed in the northern part of the Mandawa-Mahokondo area, was in part considered to be a temporal equivalent of the Upper Dinosaur Member of the Tendaguru area (Hennig 1937a). However, this correlation was questioned by Quennell et al. (1956) and Aitken (1956b, 1961).
Thickness. The GTTE estimated a thickness of $32 \mathrm{~m}$ for the Upper Dinosaur Member in the immediate surroundings of Tendaguru Hill (Aberhan et al. 2002). This measurement differs from the thickness of about $40 \mathrm{~m}$ reported by Janensch (1914a). Hennig (1933a) gave the following thickness data for the Upper Dinosaur Member: ca. $30 \mathrm{~m}$ (Tingutinguti stream section), ca. $35 \mathrm{~m}$ (Nambiranji path), $35 \mathrm{~m}$ (Dwanika stream section), and 20-25 m (Kindope stream section).

Lithofacies. Janensch (1914a) characterised the Upper Dinosaur Member as a succession of grey or reddish sandy marl alternating with friable, yellowish sandstone. According to the investigations of the GTTE, the member is mainly built up by ripple cross-bedded, finegrained sandstone and siltstone with intercalated claystone layers and isolated micritic carbonate, in part dolomite layers (Aberhan et al. 2002).

At the base, thinning-upward sequences composed of small-scale trough and ripple cross-bedded, fine-grained sandstone occur, some of which contain heavy mineral concentrations. The middle and upper part is formed mainly of ripple cross-bedded and occasionally smallscale cross-bedded, fine-grained sandstone and siltstone with minor claystone layers and some dolomite beds.

Boundaries. The lower boundary is marked by the first appearance of monotonous, ripple cross-laminated, fine-grained sandstone and siltstone on top of crossbedded, medium- to fine-grained sandstone of the Indotrigonia africana Member. The change in grain-size reflects a gradual environmental shift rather than an abrupt change and thus is a largely undisturbed, conformable contact. In contrast, the upper contact to the Rutitrigonia bornhardti-schwarzi Member is distinctly unconformable, with a sharp change in grain-size and indicators of substantial erosion and reworking of sediments of the Upper Dinosaur Member.

Palaeontolgy. Significant vertebrate fossils recorded from the Upper Dinosaur Member include fishes (e.g. Hybodus sp., Lonchidion sp., Sphenodus sp., Engaibatis schultzei, and Lepidotes tendaguruensis; Hennig 1914c; Arratia \& Schultze 1999; Arratia et al. 2002), as yet unidentified sphenodontians (Aberhan et al. 2002; Heinrich 2003), crocodiles (Bernissartia sp.; Heinrich et al. 2001; Aberhan et al. 2002; Heinrich 2003), pterosaurs (Dsungaripteroidea indet., Rhamphorhynchoidea indet.; Reck 1931; Unwin \& Heinrich 1999; Heinrich 2003), and dinosaurs (e.g. Elaphrosaurus bambergi, 'Ceratosaurus (?) roechlingi' [= basal ceratosaur; Rauhut 2005], 'Labrosaurus (?) stechowi' [= in part apparently a spinosaurid theropod; Buffetaut 2008], 'Megalosaurus (?) ingens', 'Barosaurus' africanus' [= Torneria africana; Remes 2006], Dicraeosaurus sattleri, Australodocus bohetii, Brachiosaurus brancai, Janenschia robusta, Tendaguria tanzaniensis, and Kentrosaurus aethiopicus (e.g. Janensch 1914c, 1925a, 1929a, 1935, 1950b, 1955, 1961a; Hennig 1925; Galton 1981, 1982a, 1982b, 1983; Bonaparte et al. 2000; Rauhut 2005; Re- 
mes 2006, 2007), and a mammal (Brancatherulum tendagurense; Dietrich 1927b; Simpson 1928).

The principal macroinvertebrates recorded from the Upper Dinosaur Member include bivalves (e.g. Eomiodon cutleri (Figs 5C-D), 'Mytilus cf. gallinnei' [= Falcimytilus dietrichi]; Dietrich 1914; Hennig 1914b; Quennell et al. 1956; Aberhan et al. 2002), gastropods (e.g. Physa tendagurensis; Hennig 1914b), and arthropods (Estheria tendagurensis; Janensch 1933; Cypridea sp. 5; Sames 2008).

Conifer remains recovered from the Upper Dinosaur Member (Kit 1) were identified as Semicircoporoxylon fruticulosum (Süss \& Schultka 2006). Conites araucarioides was previously described by Gothan (1927).

Age. Most workers placed the Jurassic/Cretaceous boundary at the base of the Rutitrigonia bornbardtischwarzi Member and considered the Upper Dinosaur Member as Late Jurassic (e.g. Schuchert 1918, 1934; Parkinson 1930a, 1930b; Dietrich 1933a, 1933b; Spath 1928-1933; Quennell et al. 1956; Aitken 1961). This contrasts with other views that positioned the boundary at the base of (e.g. Hennig 1914a; Janensch 1914a; Lange 1914; Behrendt 1918) or within the Upper Dinosaur Member (Hennig 1937a) or even within the underlying Indotrigonia africana Member (Sames 2008). This latter assignment, however, requires further study. $\mathrm{U}-\mathrm{Pb}$ dating of a pelvic bone from Brachiosaurus brancai of the Upper Dinosaur Member provided an age range from ca. 140 to $150 \mathrm{Ma}$ (Romer 2001) that falls approximately into the Tithonian $(150.8 \pm 4.0 \mathrm{Ma}$ to $145.5 \pm$ 4.0 Ma; Gradstein et al. 2004) and the Berriasian $(145.5 \pm 4.0 \mathrm{Ma}$ to $140.2 \pm 3.0 \mathrm{Ma}$; Gradstein et al. 2004). Schrank (2005) noted the absence of Cicatricosisporites in the Upper Dinosaur Member (Dwa 6/0) and the underlying Indotrigonia africana Member that could indicate a Tithonian age of these units. More work is needed to decide unambiguously whether the Upper Dinosaur Member is wholly Late Jurassic or, in part, Early Cretaceous.

\section{Rutitrigonia bornhardti-schwarzi Member}

Figures 2, 3, 4G-H, Table 2

Name. The uppermost of the three marine units of the Tendaguru Formation was originally named "Obere Sandsteinzone mit Trigonia schwarzi” (Janensch 1914a) (Trigonia schwarzi Bed). Later the term "Trigonia bornhardti-schwarzi Zone" (or "Stage") (e.g. Hennig 1937a) or "Schwarzistufe" (Dietrich 1933a) was applied (Table 2). According to Hennig (1914a), the member includes strata which were formerly described by Fraas (1908) from several localities in the Tendaguru area under the names "Kalksandsteine mit Trigonia schwarzi" [Tshikotshia (Majembe) stream section, eastern face of the Likonde-Kitale Plateau, and Pile-Pile], "Ntandischichten" (with Trigonia bornhardti, Ntandi Hill west of Likonde-Kitale Plateau), and Niongala Beds (with Trigonia bornhardti, Niongala north of Tendaguru
Hill) (Fig. 1). Janensch (1914a) applied the term "Obere Sandsteinzone mit Trigonia schwarzi" for strata exposed at the top of Tendaguru Hill.

The stratigraphic ranges of both Rutitrigonia bornhardti (Figs 5H-I) and Rutitrigonia schwarzi (Fig. 5G) are not sufficiently known. They are said to be mutually exclusive (Aitken 1961) but the order of superposition is disputed. Dietrich (1933a) considered Trigonia schwarzi to be stratigraphically older than Trigonia bornhardti, whereas, conversely, Hennig (1937a) believed that the latter species preceded the former one. Aitken (1961) did not rule out that Rutitrigonia bornhardti occurs only at horizons below those with the "group of Rutitrigonia schwarzi", but emphasised that the definite subdivision requires further study of the temporal distribution of Rutitrigonia. Nevertheless, from the existing evidence it can be concluded that apparently neither Rutitrigonia schwarzi nor Rutitrigonia bornhardti occurs throughout the whole member. Therefore, the broader term Rutitrigonia bornhardtischwarzi Member is adopted here to designate the uppermost of the three marine units of the Tendaguru Formation.

Type section. Quennell et al. (1956) argued that Tendaguru Hill should be regarded as type locality. However, neither the GTE nor the BTE designated a type section for the Rutitrigonia bornhardti-schwarzi Member. Here, we refrain from defining a type section of the Rutitrigonia bornhardti-schwarzi Member because of its strongly reduced thickness at Tendaguru Hill. The formal establishment of a type section has to await the detailed investigation of more extended exposures in the hinterland of Lindi, e.g. at the Kikomolela Plateau (see below).

Distribution. Strata of the Rutitrigonia bornhardtischwarzi Member are represented in much of the hinterland of Lindi and Kilwa. The general distribution of the member is shown in outline on the geological map $(1: 300,000)$ by Hennig (1914a). It extends along the western face of the Lipogiro Plateau and is exposed in the flanks of the Kikomolela Plateau, Nemba Hill, Mahimira Hill, Namunda, Likonde-Kitale, and Likonde-Kitutu plateaus at some distance southeast and east of Tendaguru Hill (Fig. 1). North of Tendaguru Hill, outcrops occur along the sides of the Mbemkuru river valley north of Kijenjere and in Itukuru. Yet farther to the north, the member crops out along the slopes of the eastern and northern part of the Kiturika Plateau, and it also occurs in a larger area through which the Nangarombe and Litandaivala rivers flow, southwest of Manganya (Fig. 1). In addition to these principal regions, there are several outliers of small areal extent such as at the top of Tendaguru Hill, where only a small part of the member is exposed due to erosion, at Runjo, Mchuya, and in the surroundings of Makangaga in the far north. The easternmost outlier of the Rutitrigonia bornhardti-schwarzi Member was reported from the western face of Kitulo Hill near Lindi (Hennig 1937a). 
Several significant fossiliferous outcrops that are considered to be equivalents of the Rutitrigonia bornhardti-schwarzi Member have been described by Aitken (1961). They are located in the Namitambo stream valley (with Eulytoceras cf. kikadiense); the Kikundi stream section, where calcareous, pebbly grit just below the unconformity with the overlying Albian marl produced Rutitrigonia bornhardti; the Nloweka stream section, where calcareous grit is exposed below the limestone of the Nloweka cliffs; near Mirumba village; in the Lihimaliao stream section; and the Runjo stream section, with an exposure of massive, grey, medium- to coarse-grained, sometimes pebbly, calcareous grit.

A notable section of the Rutitrigonia bornhardtischwarzi Member was described from the north-western face of the Kikomolela Plateau, located approximately $30 \mathrm{~km}$ northwest of Lindi (Hennig 1937a). It rests on marls identified as Upper Dinosaur Member. Interbedded in the succession of marine strata is a dinosaur-bearing bed ("Sauriermergel") that has produced a huge sauropod caudal vertebra identified tentatively as titanosaurid dinosaur (Hennig 1937a). If properly identified, the Kikomolela section contains a fourth dinosaur member in the Tanzanian coastal region deposited during the Early Cretaceous (Hennig 1937a). This is an important point that should be considered in future work on the stratigraphical subdivision of the Tendaguru Formation.

Thickness. Janensch (1914a) and Aberhan et al. (2002) estimated a thickness of approximately $5 \mathrm{~m}$ at the top of Tendaguru Hill, but the Rutitrigonia bornhardtischwarzi Member has been shown to reach a thickness of up to about $70 \mathrm{~m}$ at the Ngarama Plateau and $40 \mathrm{~m}$ at the Kikomolela Plateau (Hennig 1937a).

Lithofacies. Janensch (1914a) described the sequence of strata as consisting of fossiliferous, yellow-brown, massive calcareous sandstone with nodular concretions ("Kugelsandstein") that is overlain by whitish, calcareous coarse-grained sandstone containing quartz, feldspar, granitic pebbles, and bivalves and corals. In the Tendaguru area, the GTTE recognised a basal conglomerate overlain conformably by trough cross-bedded or ripple-bedded, medium- to fine-grained sandstone that forms fining-upward sequences and is followed by siltstone and claystone (Aberhan et al. 2002). At Tendaguru summit, a basal conglomerate consisting mainly of quartz pebbles with numerous sedimentary lithoclasts is overlain by fine- to medium-grained sandstone with variable amounts of calcite cement, which contains fragments of bivalves and echinoderms. In the Namunda Plateau, the basal conglomerate is overlain by fine-grained, trough cross-bedded sandstone, by ripple cross-bedded siltstone and by horizontally laminated claystone, which is in part bioturbated. Here, the basal conglomerate contains abundant, moderately rounded basement (gneiss) clasts and numerous sedimentary lithoclasts. When compared to the sandstone of the Nerinella and Indotrigonia africana members, this sandstone exhibits higher potassium/plagioclase feldspar-ratios.
Boundaries. A basal conglomerate which consists of quartz pebbles and clasts of reworked mudstone of the Upper Dinosaur Member and overlies an erosive contact, signals the lower boundary of the Rutitrigonia bornhardti-schwarzi Member. It implies a substantial break in sedimentation and extensive erosion of underlying sediments of the Upper Dinosaur Member during the initial deposition of the Rutitrigonia bornhardtischwarzi Member. In the Tendaguru area, the lower boundary is only exposed at Tendaguru Hill. The upper boundary to the Makonde Formation is present in the Namunda Plateau south of Tendaguru Hill, but exposure is poor. In areas east and northeast of Tendaguru, the Rutitrigonia bornhardti-schwarzi Member is overlain by Urgonian-type limestone (Hennig 1937a), most probably with conformable contact, reflecting a gradual change from a mixed siliciclastic-carbonate to a predominantly carbonate depositional environment.

Palaeontolgy. The sediments of the Rutitrigonia bornhardti-schwarzi Member have yielded abundant invertebrate fossils in many places. These include annelids (e.g. Serpula concava, Serpula triangulata; Lange 1914), corals (e.g. Astrocoenia colliculosa, A. subornata, Thamnastrea tendagurensis, Pleurosmilia hennigi; Weissermel 1900; Dietrich 1926), bivalves (e.g. Arctostrea rectangularis, 'Astarte' [=Seebachia $]$ krenkeli, 'Cardium (Tendagurium)' [= Integricardium] rothpeltzi, Exogyra couloni, 'Gervilleia' [= Gervillaria $]$ alaeformis, Megacucullaea kraussi, Plagiostoma euplocum, Pholadomya gigantea, Prohinnites fraasi, Protocardia schencki, Tancredia tellina, Rutitrigonia bornhardti, Rutitrigonia schwarzi, Sphaera corrugata; Müller 1900; Krenkel 1910; Dietrich 1914, 1933a; Lange 1914; Quennell et al. 1956; Aitken 1961); gastropods (Chenopus eurypterus, Chrysostoma staffi, Natica crassitesta, Pleurotomaria janenschi, Trochus brancai; Dietrich 1914; Quennell et al. 1956), cephalopods (e.g. Nautilus dietrichi, Phylloceras deplanatum, Lytoceras hennigi, Holcostephanus crassus, Holodiscus inflatus, Hoplites cf. neocomiensis, Crioceras sp., Parahoplites martini, Hamulina cf. quenstedti, Belemnites pistilliformis, Duvalia elegantissima; Zwierzycki 1914; Hennig 1937a; Quennell et al. 1956), brachiopods (e.g. Kingena transiens, Rhynchonella rauffi, Zeilleria dubiosa; Lange 1914), echinoderms (Pygurus sp.; Krenkel 1910), and arthropods (e.g. Glyphea hennigi; Beurlen 1933).

Plant microfossils are poorly known and include land-derived sporomorphs such as Classopollis (Aberhan et al. 2002). In addition, a marine Muderongia-Oligosphaeridium dinoflagellate cyst assemblage with $\mathrm{Mu}$ derongia tetracantha, Oligosphaeridium complex, Oligosphaeridium pulcherrimum etc., recovered from GTTE site Nam $1 \mathrm{~b}$ at the Namunda Platea, probably also belongs to the Rutitrigonia bornhardti-schwarzi Member (Schrank 2005).

Age. The Rutitrigonia bornhardti-schwarzi Member contains a variety of molluscs attributable to the Valanginian to Hauterivian (Krenkel 1910), Neocomian (Beh- 
rend 1918), lower-middle Neocomian (Lull 1915), late Valanginian to early Aptian (Dietrich 1933a) or Hauterivian to Aptian (Spath 1928-1933).

\section{Palaeoenvironmental interpretation of the Tendaguru Formation at its type locality}

The interpretation of depositional environments represented in the Tendaguru Formation is based on the association of ten distinct and recurring lithofacies types (see Aberhan et al. 2002: table 1) and the ecological requirements of the fossils. The upper portion of the Lower Dinosaur Member is tentatively assigned to a tidal flat environment with salinity variations and relatively long exposure times exerting a certain degree of environmental stress (Aberhan et al. 2002). Ostracods recovered from Tin 0a suggest a mesohaline to euhyaline aquatic environment (Sames 2008). This is in accordance with earlier interpretations by Janensch (1914a) who regarded the dinosaur-bearing beds as mud deposits of shallow-water lagoons, although this lagoon should have been of an open type with extensive tidal flats and tidal channels.

The composition of benthic molluscs and foraminifera, euhaline to mesohaline ostracods, and dinoflagellate assemblages indicate marine, shallow water conditions for the Nerinella Member, in particular for the lower part (Aberhan et al. 2002; Schrank 2005; Sames 2008). Sedimentation occurred as tidal channel fills, subtidal and tidal sand bars, minor storm layers (tempestites), and beach deposits. Overall, the Nerinella Member represents a variety of shallow subtidal to lower intertidal environments influenced by tides and storms (Aberhan et al. 2002).

The sedimentological characteristics of the basal part of the Middle Dinosaur Member suggest deposition on tidal flats and in small tidal channels of a lagoonal palaeoenvironment (Aberhan et al. 2002). The ostracod Bythocypris sp. from Tin 7a indicates polyhaline to euhaline conditions (Sames 2008). Slightly higher up (Tin 7b), a faunal sample dominated by the bivalve Eomiodon and an ostracod assemblage composed of brackish to freshwater taxa (Sames 2008) is indicative of a brackish water palaeoenvironment with distinct influx of freshwater as revealed by the nonmarine ostracod genus Cypridea, charophytes, and other freshwater algae in Tin 7d. Sames (2008) has shown that the palaeoenvironment of the ostracod assemblages of the Middle Dinosaur Member changed upsection from a marine setting in the basal parts (Tin 7a) through alternating marine-brackish conditions (Tin 7b) to freshwater conditions in the higher parts of this member (Tin $7 \mathrm{~d}$ to Tin $7 \mathrm{i}$ ). This conclusion agrees well with previous interpretations by Aberhan et al. (2002), according to which sabkha-like coastal plains with ephemeral brackish lakes and ponds are recorded in the upper part of the Middle Dinosaur Member. This part also contains pedogenic calcretes indicating subaerial exposure and the onset of soil formation.

The coarse-grained sandstone of the lower part of the Indotrigonia africana Member that shows highly variable transport directions is interpreted as deposits of large tidal channels (Aberhan et al. 2002). Grain-size, largescale sedimentary structures, and the lack of both trace fossils and epifaunal and infaunal body fossils suggest high water energy and frequent reworking. This basal succession passes upward in cross-bedded sandstone and minor siltstone and claystone with flaser or lenticular bedding that are interpreted as tidal flat and tidal channel deposits. Horizontal to low-angle cross-bedded, finegrained sandstone with intercalated bivalve pavements indicates tidal currents that operated in small flood and ebb tidal deltas and along the coast (Aberhan et al. 2002). Stacked successions of trough cross-bedded, medium- to coarse-grained sandstone of the upper part of the Indotrigonia africana Member are interpreted as tidal channel and sand bar deposits. At some places in the surroundings of Tendaguru Hill, these sediments interfinger with oolitic limestone layers that represent high-energy ooid shoals (Aberhan et al. 2002).

In the Tingutinguti stream section, the Indotrigonia africana Member exhibits several up to $20 \mathrm{~cm}$ thick, poorly sorted, conglomeratic sandstone beds. They contain mud clasts, reworked concretions and/or accumulations of thick-shelled bivalves (mainly Indotrigonia africana and Seebachia janenschi), and exhibit megaripple surfaces (Bussert \& Aberhan 2004). These conglomeratic sandstone layers are interpreted as storm deposits by Bussert \& Aberhan (2004). In the Dwanika and Bolachikombe stream sections, and in a small tributary of the Bolachikombe creek, a discrete, up to $70 \mathrm{~cm}$ thick conglomerate in the lower portion of the Indotrigonia africana Member displays evidence of a tsunami deposit (Bussert \& Aberhan 2004). All in all, lithofacies and the diverse macroinvertebrate and microfossil assemblages of the Indotrigonia africana Member suggest a shallow marine environment. Based on the diverse mesoflora and the abundance of Classopollis, a nearby vegetated hinterland is postulated that was dominated by xerophytic conifers (Aberhan et al. 2002).

The small-scale trough and ripple cross-bedded finegrained sandstone at the base of the Upper Dinosaur Member is interpreted as tidal flat deposits (Aberhan et al. 2002). Unfossiliferous sandstone in the upper part was most likely deposited in small fluvial channels in a coastal plain environment, whereas argillaceous deposits were laid down in still water bodies such as small lakes and ponds (Aberhan et al. 2002). Rare occurrences of the ostracod Cypridea in Dwa $5 \mathrm{~b} / 1$ (Sames 2008) and charophytes signal the influence of freshwater, whereas the sporadic occurrence of marine invertebrates suggests a depositional environment close to the sea (Aberhan et al. 2002).

Fining upward sequences of the basal part of the $R u$ titrigonia bornhardti-schwarzi Member are interpreted 
as tidal channel fills, the overlying fine-grained sandstone, silt- and claystone as tidal flat deposits (Aberhan et al. 2002). From the immediate surroundings of Tendaguru Hill, invertebrates and vertebrates are poorly known and limit the palaeoenvironmental interpretation of this member. The composition of the land-derived sporomorph assemblage suggests a terrestrial vegetation which was dominated by cheirolepidiacean conifers in association with ferns (Aberhan et al. 2002).

In summary, the sedimentary rocks and fossils record a repeated shift from shallow marine to tidal flat environments indicating that the strata of the Tendaguru Formation were deposited near an oscillating strandline which was controlled by sea level changes. The three dinosaur-bearing members are continental to marginal marine and the three sandstone-dominated members are marginal marine in origin.

\section{Sequence stratigraphy}

The Tendaguru Formation comprises four major depositional sequences, each bounded by unconformities at the base and at the top. These surfaces are thought to represent sequence boundaries because they are of regional extent. They mark a clear facies shift from under- to overlying sediments and partly document a significant amount of reworking of underlying sediments. Considering the presumed duration of the deposition of the Tendaguru Formation, the four sequences probably have formed as third-order sequences with an estimated duration ranging from less than one to up to a few million years (e.g. Vail et al. 1977; Haq et al. 1988; Emery \& Myers 1996). Such sequences were either forced by global sea-level change or by regional tectonism, or by an interplay of both mechanisms. The lack of detailed investigation of this stratigraphic interval in other regions of the Mandawa Basin or in neighbouring basins makes it difficult to decide which of these potential trigger mechanisms was crucial.

The lower boundary of the Lower Dinosaur Member with the basement gneiss has not yet been described in any detail. In the area west of Tendaguru, Hennig (1914a) and Janensch (1914a) envisaged a morphologically structured coastal plain with isolated gneiss hills, which was partly flooded during transgression by a very shallow sea. It is not yet clear, what kind of sediments directly overlay the gneiss. Likewise it is a matter of speculation, whether the surface was mainly shaped by subaerial exposure and erosion before the sea invaded the area or if it represents a transgressive surface sculptured at least in part by wave and/or tidal processes. In any case, it represents a nonconformity of regional extent, thus a sequence boundary which was exposed to an unkown magnitude of subaerial weathering and erosion before the sea reached the area. The Lower Dinosaur Member must therefore be considered, at least in its basal part, as forming part of a transgressive systems tract. Whether the maximum flooding surface, which marks the upper boundary of the transgressive systems tract, and overlying sediments of the highstand systems tract or of other systems tracts are documented in the Lower Dinosaur Member, is difficult to tell, mainly because of the poor outcrop situation. The occurrence of a marine fauna and of sediments characteristic of a tidal flat environment near the boundary of the Nerinella Member nevertheless leads to the conclusion that the upper part of the Lower Dinosaur Member consists of regressive sediments belonging to a highstand systems tract. This is quite similar to the situation in the Middle and Upper Dinosaur members (see below).

The lower boundaries of the Nerinella Member, the Indotrigonia africana Member, and the Rutitrigonia bornhardti-schwarzi Member to the Lower, Middle, and Upper Dinosaur Member, respectively, are of erosive nature and represent sequence boundaries. An in-depth discussion of these boundaries is limited by their generally poor exposure. Under- and overlying sediments nevertheless give conclusive evidence for the sharp and erosive character of these contacts.

Lithostratigraphically, the base of the Nerinella Member can be defined as the first appearance of poorly sorted, medium- to coarse-grained sandstone that overlies fine-grained sandstone and siltstone of the Lower Dinosaur Member. The basal sediments, trough cross-bedded or massive, medium- to coarse-grained sandstone which contains abundant bioclasts indicating normal marine conditions, are thought to represent mainly deposits of lower intertidal or shallow subtidal channels. The lowermost exposed sandstone beds, however, are massive, fine- to medium-grained, moderately to well sorted, and contain, besides marine bivalves, abundant calcrete and mudstone clasts. Lithologically, they can be assigned to the Lower Dinosaur Member, but genetically they are interpreted to represent foreshore sediments related to the landward shift of the coastline during transgression. The basal surface below these sandstone beds resulted most probably from wave erosion in the upper shoreface and represents a transgressive or wave ravinement surface (e.g. Nummedal \& Swift 1987). The intraclasts formed as a transgressive lag from the reworking of formerly underlying palaeosols and supratidal sediments, likely indicating a relatively high amount of scouring at the base of the transgressive sediments. These intraclasts attest the former presence of non-marine or supratidal deposits, whereas the overlying sediments most probably represent very shallow subtidal to tidal channel and sand bar deposits of a normal marine environment. The basal erosion surface thus separates very shallow marine tidal sediments of the Lower Dinosaur Member from normal marine sediments of the basal part of the Nerinella Member. It is the surface of initial transgression, or wave ravinement, and forms the lower sequence boundary.

The fining-upward sequences of the basal Nerinella Member probably represent the filling of tidal channels and the migration of subtidal sand bars. It is not clear, if these sequences represent true parasequences or if 
they are the result of autocyclic processes such as local shifts and abandonments of tidal channels. Whereas the basal part of the Nerinella Member contains fauna of normal marine habitats, the upper part of the Nerinella Member - cross-bedded sandstone with only few marine bioclasts - might partly represent deposits of more shallow and stressed environments such as very shallow tidal channels and tidal sand bars. This implies that the maximum flooding surface is located below these deposits, possibly at the top of the fining-upward sequences of the basal Nerinella Member, but a condensed section is either missing or was not discovered during field work. Carter et al. (1998) addressed the problem of identifying the position of the maximum flooding surface in outcrops and suggested that this boundary be allowed to remain unspecified or unknowable. In any case, the upper part of the Nerinella Member was deposited during the late stage of base-level rise, when littoral sediments were starting to aggrade and to prograde into the basin. Thus it constitutes part of the highstand systems tract. Forming a rather thick and monotonous succession, these sediments imply a relatively high rate of aggradation due to continuous base-level rise.

The contact to the Middle Dinosaur Member, although not well exposed, most probably is conformable and gradual, suggesting that sedimentation had slowly outpaced base-level rise. The overlying Middle Dinosaur Member was deposited in a tidally influenced shallow lagoonal environment and contains facies indicative of subaerial exposure and soil development in its upper part. Yet, no strong subaerial unconformity and therefore no major sequence-bounding surface exists, because the paleosols are overlain by sediments that are lithologically and genetically very similar to the underlying deposits, contradicting an abrupt shift in facies. The upper part of the Nerinella Member and the Middle Dinosaur Member jointly form a more or less continuous sequence of aggrading and prograding shallow marine and littoral sediments above a maximum flooding surface and can therefore be considered to represent a highstand systems tract. It remains speculative if deposits of a lowstand systems tract, e.g. fluvial sediments, were once present at the top of the Middle Dinosaur Member, but were subsequently eroded by wave and/or tidal activity during the following transgression.

The lower boundary of the Indotrigonia africana Member is clearly erosive, and the result, at least partly, of tidal channel scouring during shoreline transgression, thus representing a transgressive and/or tidal ravinement surface. Tidal channel sandstones in the basal part of the Indotrigonia africana Member contain heavy mineral concentrations which are comparable to transgressive lag deposits. Heavy mineral concentrations resulted from wave and tidal reworking in near-shoreface environments and their accumulation in tidal channels. Heterolithic sediments likely represent mixed sand-mud tidal flat and tidal channel deposits. Overlying shoreface sandstones which are punctuated by tem- pestites might enclose the maximum flooding surface or they alternatively can be considered as the "condensed section systems tract" (Carter et al. 1998). Up to these beds, the basal part of the Indotrigonia africana Member belongs to the transgressive systems tract. These sediments are overlain by tidal channel and tidal sand bar deposits that likely record the progradation of tidal deposits onto shoreface sediments and therefore already form part of the highstand systems tract. The regressive trend within the upper Indotrigonia africana Member continues without a significant break in sedimentation or an abrupt facies change to the tidal flat and lagoonal sediments of the Upper Dinosaur Member. Similar to the Middle Dinosaur Member, this member contains micritic carbonate layers of supratidal origin and in addition sandstone lenses which were deposited in small fluvial channels. A major break in sedimentation nevertheless does not seem to have occurred.

The Rutitrigonia bornhardti-schwarzi Member overlies the Upper Dinosaur Member with a basal conglomerate above an erosional contact. The overlying crossbedded sandstone that forms fining-upward sequences and contains trigonid bivalves, is interpreted as tidal channel fills. The basal boundary to the lagoonal and tidal flat sediments of the Upper Dinosaur Member is therefore interpreted as a transgressive ravinement surface and the overlying shallow marine sediments of the Rutitrigonia bornhardti-schwarzi Member as the basal part of a transgressive systems tract. The incomplete preservation of the Rutitrigonia bornhardti-schwarzi Member in the Tendaguru area prevents any further sequence stratigraphic interpretation.

The Tendaguru Formation contains four third-order sequences that consist basically of transgressive and highstand systems tracts. Sequence boundaries are formed by transgressive ravinement surfaces and by maximum flooding surfaces, albeit the latter are difficult to identify. For the Rutitrigonia bornhardti-schwar$z i$ Member, the existence of a highstand systems tract is likely, but, because of its fragmentary preservation, cannot be proven in the Tendaguru area. It is also questionable, whether deposits of lowstand systems tracts are preserved at the top of the Middle and Upper Dinosaur members.

Considering the difficulties in identifying the maximum flooding surface and in differentiating the highstand normal regressive from the lowstand normal regressive sediments, the four major depositional sequences of the Tendaguru Formation might be subdivided in a simple way into transgressive-regressive sequences thus into transgressive and regressive systems tracts (Embry \& Johannessen 1992).

The transgressive systems tracts consist mainly of shallow marine shoreface, tidal channel, and sand bar sandstone, the highstand systems tracts (or regressive systems tracts) predominantly of shallow tidal channel, tidal flat, and marginal lagoonal to supratidal deposits. The sedimentation and preservation of fine-grained lagoonal and tidal sediments is likely related to a low-gra- 
dient ('shelf') setting, a flat topography at the shoreline and a moderate mixed tide-wave environment in the shelf sea. The general decrease of the grain-size of the sediments towards the shoreline as well as the almost complete lack of fluvial deposits in the highstand systems tract indicates that the majority of sand was not supplied by rivers of the direct hinterland but was introduced from entry points farther away by longshore currents.

\section{Conclusions}

Utilising all available sedimentological and palaeontological data, including those obtained by the recent German-Tanzanian Tendaguru Expedition, we are in the position to formally define the Tendaguru Formation and its six constituent members. These are, from bottom to top, the Lower Dinosaur Member, Nerinella Member, Middle Dinosaur Member, Indotrigonia africana Member, Upper Dinosaur Member, and Rutitrigonia bornhardti-schwarzi Member. In the Tendaguru area, outcrops of the Lower Dinosaur Member are limited and the establishment of a type section for this member has to await the discovery of more extended exposures. Due to the greatly reduced thickness of the Rutitrigonia bornhardti-schwarzi Member at Tendaguru Hill, the designation of its type section requires the investigation of more extended exposures outside the Tendaguru area.

In its type area, the Tendaguru Formation was deposited in a marginal marine to continental setting. The various palaeoenvironments comprise tide-influenced, shallow subtidal, marine environments above fair weather wave base, extended tidal flats with tidal channels, brackish lakes and ponds, and low relief coastal plains, dissected by small fluvial channels and with pools in the intervening areas.

In terms of sequence stratigraphy, the Tendaguru Formation comprises four third-order sequences which are composed of transgressive and highstand systems tracts. Sequence boundaries are represented by transgressive ravinement surfaces and maximum flooding surfaces. The latter are difficult to identify and, therefore, a subdivision of the depositional sequences into transgressive and regressive systems tracts is more straightforward.

The age of the Tendaguru Formation ranges at least from the middle Oxfordian to the Hauterivian or possibly Aptian, but the exact chronostratigraphy of its members still needs to be established. The placement of the Jurassic/Cretaceous boundary within the Tendaguru Formation is as yet uncertain.

\section{Acknowledgements}

We thank József Pálfy, Hans-Peter Schultze, and Günter Schweigert for helpful reviews of the manuscript. We extend our sincere thanks to the members of the German-Tanzanian Tendaguru Expedition 2000: Remigius Chami, Oliver Hampe, Saidi Kapilima, Gerhard
Maier, Emma Msaky, Benjamin Sames, Eckhard Schrank, and Stephan Schultka. This work was supported by grants from the Deutsche Forschungsgemeinschaft (DFG) which are acknowledged with gratitude. Gerhard Maier critically read the manuscript and improved the English. Mrs. C. Radtke and Mrs. E. Siebert assisted the preparation of Figure 5. The editorial work of Dieter Korn and Florian Witzmann is appreciated.

\section{References}

Aberhan, M., Bussert, R., Heinrich, W.-D., Schrank, E., Schultka, S., Sames, B., Kriwet, J. \& Kapilima, S. 2002. Palaeoecology and depositional environments of the Tendaguru Beds (Late Jurassic to Early Cretaceous, Tanzania). - Mitteilungen aus dem Museum für Naturkunde in Berlin, Geowissenschaftliche Reihe 5: 17-42.

Aitken, W. G. 1954. Notes on the Mandawa-Mahokondo anticline, Kilwa District. - Records of the Geological Survey of Tanganyika 1 (1954): 3-5.

Aitken, W. G. 1956a. Southern Kilwa District. - Records of the Geological Survey of Tanganyika 4 (1954): 1-2.

Aitken, W. G. 1956b. The Jurassic-Cretaceous junction in Tanganyika. East-Central Regional Committee for Geology, Commission for Technical Cooperation in Africa south of the Sahara 1956: 67-71.

Aitken, W. G. 1957. Further notes on the Mandawa-Mahokondo anticline, Kilwa District. - Records of the Geological Survey of Tanganyika 3 (1956): 8-16.

Aitken, W. G. 1958. Notes on the Makangaga-Ruawa anticline, Kilwa District. - Records of the Geological Survey of Tanganyika 5 (1955): 5-17.

Aitken, W. G. 1961. Geology and Palaeontology of the Jurassic and Cretaceous of Southern Tanganyika. - Bulletin of the Geological Survey of Tanganyika 31: 1-144.

Arkell, W. J. 1956. Jurassic Geology of the World. Oliver and Boyd Ltd., Edinburgh.

Arratia, G., Kriwet, J. \& Heinrich, W.-D. 2002. Selachians and actinopterygians from the Upper Jurassic of Tendaguru, Tanzania. Mitteilungen aus dem Museum für Naturkunde in Berlin, Geowissenschaftliche Reihe 5: 205-228.

Arratia, G. \& Schultze, H.-P. 1999. Semionotiform fish from the Upper Jurassic of Tendaguru (Tanzania). - Mitteilungen aus dem Museum für Naturkunde in Berlin, Geowissenschaftliche Reihe 2: $135-153$.

Balduzzi, A. Msaky, W., Tricianti, E. \& Manum S. B. 1992. Mesozoic Karroo and post-Karroo formations in the Kilwa area, southeastern Tanzania - a stratigraphic study based on palynology, micropalaeontology and well log data from the Kizimbani well. - Journal of African Earth Sciences 15: 405-427.

Behrend, F. 1918. Die Stratigraphie des östlichen Zentralafrika unter Berücksichtigung der Beziehungen zu Südafrika. - Beiträge zur geologischen Erforschung der Deutschen Schutzgebiete 15: 1148.

Beurlen, K. 1933. Crustacea Decapoda aus den Tendaguru-Schichten. - Palaeontographica, Supplement VII, 2. Reihe, Teil 2, Lieferung 1: 87-94.

Bonaparte, J. F., Heinrich, W.-D. \& Wild, R. 2000. Review of Janenschia Wild, with the description of a new sauropod from the Tendaguru beds of Tanzania and a discussion on the systematic value of procoelus caudal vertebrae in the sauropoda. - Palaeontographica, Abteilung A 256 (1-3): 25-76.

Bornhardt, W. 1900. Zur Oberflächengestaltung und Geologie Deutsch-Ostafrikas. Deutsch-Ostafrika 7. Dietrich Reimer, Berlin.

Broschinski, A. 1999. Ein Lacertilier (Scincomorpha, Paramacellodidae) aus dem Oberen Jura von Tendaguru (Tansania). - Mitteilungen aus dem Museum für Naturkunde Berlin, Geowissenschaftliche Reihe 2: 155-158. 
Buffetaut, E. 2008. Spinosaurid teeth from the Late Jurassic of Tendaguru, Tanzania, with remarks on the evolutionary and biogeographical history of the Spinosauridae. In Mazin, J.-M., Hantzpergue, P. \& Lacombe, V. (eds). Mid-Mesozoic Life and Environments. Documents des Laboratoires de Geologie de Lyon 164: 26-28.

Bussert, R. \& Aberhan, M. 2004. Storms and tsunamis: evidence of event sedimentation in the late Jurassic Tendaguru Beds of southeastern Tanzania. - Journal of African Earth Sciences 39: 549555.

Carter, R. M., Fulthorpe, C. S. \& Naish, T. R. 1998. Sequence concepts at seismic and outcrop scale: the distinction between physical and conceptual stratigraphic surfaces. - Sedimentary Geology 122: 165-179.

Chen, Y. Y. 1982. Recognition of the dinocyst genus Komewuia, with assignable species from Madagascar. - Micropaleontology 28: 31-42.

Cox, L. R. 1952. The Jurassic lamellibranch fauna of Cutch (Kachh). No. 3: Families Pectinidae, Amusiidae, Plicatulidae, Limidae, Ostreidae and Trigonidae (Supplement). - India Geological Survey Memoires, Palaeontologica Indica, ser. 9, vol. 3, part 4: 1-128.

Cox, L. R. 1965. Jurassic Bivalvia and Gastropoda from Tanganyika and Kenya. - Bulletin of the British Museum (Natural History), Supplement 1: 3-213.

Dacqué, E. \& Krenkel, E. 1909. Jura und Kreide in Ostafrika. Neues Jahrbuch für Mineralogie, Geologie und Paläontologie, Beilage-Band 28: 150-232.

Dietrich, W. O. 1914. Die Gastropoden der Tendaguruschichten, der Aptstufe und der Oberkreide im südlichen Deutsch-Ostafrika. Archiv für Biontologie 3 (4): 97-153.

Dietrich, W. O. 1925a. Über eine dem mittleren Sauriermergel am Tendaguru äquivalente, rein marine Kimmeridgebildung in Mahokondo, Deutsch-Ostafrika. - Palaeontographica, Supplement VII, 2. Reihe, Teil 1, Lieferung 1: 1-24.

Dietrich, W. O. 1925b. Zur Kenntnis der Urgongesteine im südlichen Deutsch-Ostafrika nebst Beschreibung der darin vorkommenden Orbitolinen. - Palaeontographica, Supplement VII, 2. Reihe, Teil 1, Lieferung 1: 25-40.

Dietrich, W. O. 1926. Steinkorallen des Malms und der Unterkreide im südlichen Deutsch-Ostafrika. - Palaeontographica, Supplement VII, 2. Reihe, Teil 1, Lieferung 1: 41-102.

Dietrich, W. O. 1927a. Das Alter der Trigonienschichten am Tendaguru. - Centralblatt für Mineralogie, Geologie und Paläontologie, Abteilung B 1927 (2): 59-64.

Dietrich, W. O. 1927b. Brancatherulum n. g., ein Proplacentalier aus dem obersten Jura des Tendaguru in Deutsch-Ostafrika. - Centralblatt für Mineralogie, Geologie und Paläontologie, Abteilung B 1927 (10): 423-426.

Dietrich, W. O. 1933a. Zur Stratigraphie und Palaeontologie der Tendaguruschichten. - Palaeontographica, Supplement VII, 2. Reihe, Teil 2, Lieferung 1: 1-86.

Dietrich, W. O. 1933b. Zur Stratigraphie der Tendaguruschichten in Deutschostafrika. - Centralblatt für Mineralogie, Geologie und Paläontologie, Abteilung B 1933: 423-428.

Embry, A. F. \& Johannessen, E. P. 1992. T-R sequence stratigraphy, facies analysis and reservoir distribution in the uppermost Triassic-Lower Jurassic succession, western Sverdrup Basin, Arctic Canada. In Vorren, T. O., Bergsager, E., Dahl-Stamnes, O. A., Holter, E., Johansen, B., Lie, E. \& Lund, T. B. (eds). Arctic Geology and Petroleum Potential. Norwegian Petroleum Society Special Publication 2, Amsterdam: pp. 121-146.

Emery, D. \& Myers, K. J. 1996. Sequence Stratigraphy. Blackwell, Oxford.

Fahrion, H. 1937. Die Foraminiferen der Kreide- und Tertiär-Schichten im südlichen Deutsch-Ostafrika. - Palaeontographica, Supplement VII, 2. Reihe, Teil 2, Lieferung 2: 187-216.

Fraas, E. 1908. Ostafrikanische Dinosaurier. - Palaeontographica 55: $105-144$.

Furon, R. 1963. Geology of Africa. Hafner, New York.
Galton, P. M. 1977. The ornithopod dinosaur Dryosaurus and a Laurasia-Gondwanaland connection in the Upper Jurassic. - Nature 268: 230-232.

Galton, P. M. 1981. Dryosaurus, a hypsilophodontid dinosaur from the Upper Jurassic of North America and Africa. - Paläontologische Zeitschrift 55 (3/4): 271-312.

Galton, P. M. 1982a. The postcranial anatomy of stegosaurian dinosaur Kentrosaurus from the Upper Jurassic of Tanzania, East Africa. - Geologica et Palaeontologica 15: 139-160.

Galton, P. M. 1982b. Elaphrosaurus, an ornithomimid dinosaur from the Upper Jurassic of North America and Africa. - Paläontologische Zeitschrift 56 (3/4): 265-275.

Galton, P. M. 1983. The cranial anatomy of Dryosaurus, a hypsilophodontid dinosaur from the Upper Jurassic of North America and East Africa, with a review of hypsilophodontids from the Upper Jurassic of North America. - Geologica et Palaeontologica 17: 207-243.

Geiger, M., Clark, D. N. \& Mette, W. 2004. Reappraisal of the timing of the break-up of Gondwana based on sedimentological and seismic evidence from the Morondava Basin, SW Madagascar. Journal of African Earth Sciences 338: 363-381.

Geiger, M. \& Schweigert, G. 2006. Toarcian-Kimmeridgian depositional cycles of the south-western Morondava Basin along the rifted continental margin of Madagascar. - Facies 52: 85-112.

Gothan, W. 1927. Ein araucarioider Coniferenzapfen aus den Tendaguruschichten. - Palaeontographica, Supplement VII, 2. Reihe, Teil 1, Lieferung 3: 103-106.

Gradstein, F. M., Ogg, J. G., Smith, A. G., Bleeker, W. \& Lourens, L. J. 2004. A new geologic time scale, with special reference to Precambrian and Neogene. - Episodes 27 (2): 83-100.

Gregory, J. W. 1921. The rift valleys and geology of East Africa. Seeley, Service and Co. Ltd, London.

Hallam, A. 2001. A review of the broad pattern of Jurassic sea-level changes and their possible causes in the light of current knowledge. - Palaeogeography, Palaeoclimatology, Palaeoecology 167: 23-37.

Hancox, P. J., Brandt, D. \& Edwards, H. 2002. Sequence stratigraphic analysis of the Early Cretaceous Maconde Formation (Rovuma basin), northern Mozambique. - Journal of African Earth Sciences 34: 291-297.

Hankel, O. 1994. Early Permian to Middle Jurassic rifting and sedimentation in East Africa and Madagascar. - Geologische Rundschau 83: 703-710.

Haq, B. U., Hardenbol, J. \& Vail, P. 1988. Mesozoic and Cenozoic chronostratigraphy and cycles of sea-level change. In Wilgus, C. K., Hastings, B., Kendall, C. G. S. C., Posamentier, H. W., Ross, C. A. \& Van Wagoner, J. C. (eds). Sea-Level Change - An Integrated Approach. SEPM Special Publication 42, Tulsa: pp. 71-108.

Haughton, S. H. (ed.) 1938. Lexicon de Stratigraphie. Volume I: Africa. Thomas Murby \& Co., London.

Heinrich, W.-D. 1998. Late Jurassic mammals from Tendaguru, Tanzania, East Africa. - Journal of Mammalian Evolution 5 (4): 269-290.

Heinrich, W.-D. 1999a. The taphonomy of dinosaurs from the Upper Jurassic of Tendaguru, Tanzania (East Africa), based on field sketches of the German Tendaguru expedition (1909-1913). Mitteilungen aus dem Museum für Naturkunde in Berlin, Geowissenschaftliche Reihe 2: 25-61.

Heinrich, W.-D. 1999b. First haramiyid (Mammalia, Allotheria) from the Mesozoic of Gondwana. - Mitteilungen aus dem Museum für Naturkunde Berlin, Geowissenschaftliche Reihe 2: 159-170.

Heinrich, W.-D. 2001. New records of Staffia aenigmatica (Mammalia, Allotheria, Haramiyida) from the Upper Jurassic of Tendaguru in southeastern Tanzania, East Africa. - Mitteilungen aus dem Museum für Naturkunde in Berlin, Geowissenschaftliche Reihe 4: 239-255.

Heinrich, W.-D. 2003. Expeditionen in die Erdgeschichte Ostafrikas: Die Dinosaurierlagerstätte Tendaguru in Tansania. - Sitzungsberichte der Gesellschaft Naturforschender Freunde zu Berlin, Neue Folge 42: 5-30. 
Heinrich, W.-D., Bussert, R., Aberhan, M., Hampe, O., Kapilima, S., Schrank, E., Schultka, S., Maier, G., Msaky, E., Sames, B. \& Chami, R. 2001. The German-Tanzanian Tendaguru Expedition 2000. Mitteilungen aus dem Museum für Naturkunde in Berlin, Geowissenschaftliche Reihe 4: 223-237.

Hennig, E. 1912a. Am Tendaguru. Leben und Wirken einer deutschen Forschungsexpedition zur Ausgrabung vorweltlicher Riesensaurier in Deutsch-Ostafrika. E. Schweizerbart'sche Verlagsbuchhandlung, Stuttgart.

Hennig, E. 1912b. Die Entstehung der Dinosaurier-Lager. - Sitzungsberichte der Gesellschaft Naturforschender Freunde zu Berlin 1912: 137-142.

Hennig, E. 1912c. Über die mögliche Ausdehnung der DinosaurierVorkommnisse im östlichen Afrika. - Sitzungsberichte der Gesellschaft Naturforschender Freunde zu Berlin 1912: 493-497.

Hennig, E. 1914a. Beiträge zur Geologie und Stratigraphie DeutschOstafrikas. I. Geologisch-stratigraphische Beobachtungen im Küstengebiet des südlichen Deutsch-Ostafrika. II. Geologisch-stratigraphische Beobachtungen im Gebiete der Jura-Ablagerungen an der Deutsch-Ostafrikanischen Zentralbahn. - Archiv für Biontologie $3(3)$ : 1-72.

Hennig, E. 1914b. Die Invertebraten-Fauna der Saurierschichten am Tendaguru. - Archiv für Biontologie 3 (4): 155-185.

Hennig, E. 1914c. Die Fischreste unter den Funden der TendaguruExpedition. - Archiv für Biontologie 3 (4): 295-312.

Hennig, E. 1915. Kentrosaurus aethiopicus der Stegosauride des Tendaguru. - Sitzungsberichte der Gesellschaft Naturforschender Freunde zu Berlin 1915: 219-247.

Hennig, E. 1916. Zweite Mitteilung über den Stegosauriden vom Tendaguru. - Sitzungsberichte der Gesellschaft Naturforschender Freunde zu Berlin 1916: 175-182.

Hennig, E. 1924. Der mittlere Jura im Hinterlande von Daressalaam (Deutsch-Ostafrika). Beiträge zur Geologie und Stratigrapie Deutsch-Ostafrikas III. - Monographien zur Geologie und Palaeontologie, Serie 2, Heft 2: 1-131.

Hennig, E. 1925. Kentrurosaurus aethiopicus: die Stegosaurierfunde vom Tendaguru, Deutsch-Ostafrika. - Palaeontographica, Supplement VII, 1. Reihe, Teil 1, Lieferung 1: 100-253.

Hennig, E. 1927. Die Altersfragen der Tendaguru-Schichten im südlichen Deutsch-Ostafrika. - Centralblatt für Mineralogie, Geologie und Paläontologie, Abteilung B 1927 (2): 64-69.

Hennig, E. 1937a. Der Sedimentstreifen des Lindi-Kilwa-Hinterlandes (Deutsch-Ostafrika). - Palaeontographica, Supplement VII, 2. Reihe, Teil 2, Lieferung 2: 99-186.

Hennig, E. 1937b. Die ostafrikanische Bruchtreppe. - Geologische Rundschau 28: 292-295.

Hölder, H. 1964. Jura (Handbuch der stratigraphischen Geologie, 4). Enke, Stuttgart.

Janensch, W. 1912. Verlauf und Ergebnisse der Expedition. - Sitzungsberichte der Gesellschaft Naturforschender Freunde zu Berlin 1912 (2b): 124-137.

Janensch, W. 1914a. Die Gliederung der Tendaguru-Schichten im Tendaguru-Gebiet und die Entstehung der Saurier-Lagerstätten. - Archiv für Biontologie 3 (3): 227-261.

Janensch, W. 1914b. Bericht über den Verlauf der Tendaguru-Expedition. - Archiv für Biontologie 3 (1): 17-58.

Janensch, W. 1914c. Übersicht über die Wirbeltierfauna der Tendaguru-Schichten, nebst einer kurzen Charakterisierung der neu aufgestellten Arten von Sauropoden. - Archiv für Biontologie 3 (1): 81-110.

Janensch, W. 1920. Über Elaphrosaurus bambergi und die Megalosaurier aus den Tendaguru-Schichten Deutschostafrikas. - Sitzungsberichte der Gesellschaft Naturforschender Freude zu Berlin 1920: 225-235.

Janensch, W. 1925a. Die Coelurosaurier und Theropoden der Tendaguru-Schichten Deutsch-Ostafrikas. - Palaeontographica, Supplement VII, 1. Reihe, Teil 1, Lieferung 1: 1-97.
Janensch, W. 1925b. Die Grabungsstellen der Tendaguru-Gegend. Palaeontographica, Supplement VII, 1. Reihe, Teil 1, Lieferung 1: XVII-XIX.

Janensch, W. 1929a. Material und Formengehalt der Sauropoden in der Ausbeute der Tendaguru-Expedition. - Palaeontographica, Supplement VII, 1. Reihe, Teil 2, Lieferung 1: 1-34.

Janensch, W. 1929b. Die Wirbelsäule der Gattung Dicraeosaurus. Palaeontographica, Supplement VII, 1. Reihe, Teil 2, Lieferung 1: 37-133.

Janensch, W. 1929c. Ein aufgestelltes und rekonstruiertes Skelett von Elaphrosaurus bambergi. Mit einem Nachtrag zur Osteologie dieses Coelurosauriers. - Palaeontographica, Supplement VII, 1. Reihe, Teil 2, Lieferung 1: 279-286.

Janensch, W. 1933. Eine Estheria aus den Tendaguruschichten. - Palaeontographica, Supplement VII, 2. Reihe, Teil 2, Lieferung 1: 95-98.

Janensch, W. 1935. Die Schädel der Sauropoden Brachiosaurus, Barosaurus und Dicraeosaurus aus denTendaguru-Schichten DeutschOstafrikas. - Palaeontographica, Supplement VII, 1. Reihe, Teil 2, Lieferung 1: 145-248.

Janensch, W. 1950a. Die Wirbelsäule von Brachiosaurus brancai. Palaeontographica, Supplement VII, 1. Reihe, Teil 3, Lieferung 2: 27-93.

Janensch, W. 1950b. Die Skelettrekonstruktion von Brachiosaurus brancai. - Palaeontographica, Supplement VII, 1. Reihe, Teil 3, Lieferung 2: 95-103.

Janensch, W. 1955. Der Ornithopode Dysalotosaurus der Tendaguruschichten. - Palaeontographica, Supplement VII, 1. Reihe, Teil 3, Lieferung 3: 105-176.

Janensch, W. 1961a. Die Gliedmaßen und Gliedmaßengürtel der Sauropoden der Tendaguru-Schichten. - Palaeontographica, Supplement VII, 1. Reihe, Teil 3, Lieferung 4: 177-235.

Janensch, W. 1961b. Skelettrekonstruktion von Dysalotosaurus lettowvorbecki. - Palaeontographica, Supplement VII, 1. Reihe, Teil 3, Lieferung 4: 237-240.

Janensch, W. \& Hennig, E. 1914. Tabellarische Übersicht der Fundorte wirbelloser Fossilien im Arbeitsgebiete der Tendaguru-Expedition. - Archiv für Biontologie 3 (4): 1-6.

Jarzen, D. M. 1981. A preliminary report of the palynomorphs recovered from Tendaguru Hill (Tanzania). - Pollen et Spores 23 (1): 149-163.

Jiang, Q., Mungai, M. W., Downie, C. \& Neves, R. 1992. Late Jurassic dinoflagellate assemblages of the Mto Panga Quarry, Mombasa, Kenya. - Review of Palaeobotany and Palynology 74: 77100 .

Kagya, M. L. W. 1996. Geochemical characterisation of Triassic petroleum source rock in the Mandawa basin, Tanzania. - Journal of African Earth Sciences 23: 73-88.

Kahlert, E., Schultka, S. \& Süss, H. 1999. Die mesophytische Flora der Saurierlagerstätte am Tendaguru (Tansania). Erste Ergebnisse. Mitteilungen aus dem Museum für Naturkunde Berlin, Geowissenschaftliche Reihe 2: 185-190.

Kent, P. E., Hunt, J. A. \& Johnstone, D. W. 1971. The geology and geophysics of coastal Tanzania. - Natural Environment Research Council, Institute of Geological Sciences, Geophysical Paper 6: I-VI, 1-101.

Kitchin, F. L. 1929. On the age of the upper and middle dinosaur deposits at Tendaguru, Tanganyika Territory. - Geological Magazine 66 (5): 193-220.

Krenkel, E. 1910. Die untere Kreide von Deutsch-Ostafrika. - Beiträge zur Geologie und Paläontologie Österreich-Ungarns und des Orients 23: 201-250.

Krenkel, E. 1911. Zur unteren Kreide von Deutsch-Ostafrika. - Centralblatt für Mineralogie, Geologie und Paläontologie 1911: 285-288.

Krenkel, E. 1925. Geologie Afrikas. I. Teil. Borntraeger, Berlin.

Krenkel, E. 1957. Geologie und Bodenschätze Afrikas. Geest \& Portig, Leipzig. 
Kreuser, T., Wopfner, H., Kaaya, C. Z., Markwort, S., Semkiwa, P. Z. \& Aslandis, P. 1990. Depositional evolution of Permo-Triassic Karroo basins in Tanzania with reference to their economic potential. - Journal of African Earth Sciences 10: 151-167.

Lange, E. 1914. Die Brachiopoden, Lamellibranchiaten und Anneliden der Trigonia Schwarzi-Schichten. - Archiv für Biontologie 3 (4): 187-289.

Luger, P, Gröschke, M., Bussmann, M., Dina, A., Mette, W., Uhmann, A. \& Kallenbach, H. 1994. Comparison of the Jurassic and Cretaceous sedimentary cycles of Somalia and Madagascar: implications for the Gondwana breakup. - Geologische Rundschau 83 (4): 711-727.

Lull, R. S. 1915. Sauropoda and Stegosauria of the Morrison of North America compared with those of Europe and Eastern Africa. Bulletin of the Geological Society of America 26: 323-334.

Maier, G. 2003. African dinosaurs unearthed. The Tendaguru expeditions. Indiana University Press, Bloomington \& Indianapolis.

Migeod, F. W. H. 1927. British Museum East Africa expedition. Progress in the year 1926. - Natural History Magazine 1927 (1): 34-43.

Migeod, F. W. H. 1930. Report on the British Museum East Africa expedition. Season 1929. - Natural History Magazine 1930 (2): $185-198$.

Migeod, F. W. H. 1931. British Museum East Africa expedition. Account of the work done in 1930. - Natural History Magazine 1931 (3): 87-103.

Mpanda, S. 1997. Geological development of the East African coastal basin of Tanzania. - Stockholm Contributions in Geology 45 (1): $1-121$.

Msaky, E. S. 2007. Occurrence of dinoflagellate cyst genera Wanaea and Komewuia in Upper Jurassic strata, coastal Tanzania. - Paleontological Research 11 (1): 41-58.

Müller, G. 1900. Versteinerungen des Jura und der Kreide. In Bornhardt, W. (ed.). Zur Oberflächengestaltung und Geologie DeutschOstafrikas. Deutsch-Ostafrika 7. Dietrich Reimer, Berlin: pp. 514571.

Muhongo, S., Kapilima, S. \& Mtoni, Y. 1998. Geological development and mineral resources of the coastal basin of Tanzania. IOC Workshop Report 165: 209-215, 270-273.

Murphy, M. A. \& Salvador, A. 1999. International Stratigraphic Guide - An abridged version. - Episodes 22: 255-271.

Nicholas, C. J., Pearson, P. N., Bown, P. R., Dunkley Jones, T., Huber, B. T., Karega, A., Lees, J. A., McMillan, I. K., O’Halloran, A., Singano, J. M. \& Wade, B. S. 2006. Stratigraphy and sedimentology of the Upper Cretaceous to Paleogene Kilwa Group, southern coastal Tanzania. - Journal of African Earth Sciences 45: 431-466.

Nicholas, C. J., Pearson, P. N., McMillan, I. K., Ditchfield, P. W. \& Singano, J. M. 2007. Structural evolution of southern coastal Tanzania since the Jurassic. - Journal of African Earth Sciences 48: $273-297$.

Nummedal, D. \& Swift, D. J. P. 1987. Transgressive stratigraphy at sequence-bounding unconformities: some principles derived from Holocene and Cretaceous examples. In Nummedal, D. \& Price, W. A. (eds). Sea Level Fluctuation and Coastal Evolution. SEPM Special Publication 41, Tulsa: pp. 241-260.

Parkinson, J. 1929. The dinosaur deposits at Tendaguru, Tanganyika Territory. - Geological Magazine 66 (12): 558-560.

Parkinson, J. 1930a. The dinosaur in East Africa. An account of the giant reptile beds of Tendaguru, Tanganyika Territory. H. F. \& G. Witherby, London.

Parkinson, J. 1930b. A note on the geology of the country around Tendaguru, Lindi district. - Geological Survey Department, Tanganyika Territory, Short paper 6: 7-16.

Philippe, M., Bamford, M., McLoughlin, S., Alves, L. S. R., FalconLang, H. J., Gnaedinger, S., Ottone, E. G., Pole, M., Rajanikanth, A., Shoemaker, R. E., Torres, T. \& Zamuner, A. 2004. Biogeographic analysis of Jurassic-Early Cretaceous wood assemblages from Gondwana. - Review of Palaeobotany and Palynology 129: $141-173$
Quennell, A. M., McKinlay, A. C. M. \& Aitken, W. G. 1956. Summary of the geology of Tanganyika. Part 1: Introduction and Stratigraphy. - Memoirs of the Geological Survey of Tanganyika 1: $1-264$.

Rabinowitz, P. \& Woods, S. 2006. The Africa-Madagascar connection and mammalian migrations. - Journal of African Earth Sciences 48: 270-276.

Raath, M. A. \& McIntosh, J. S. 1987. Sauropod dinosaurs from the Central Zambezi Valley, Zimbabwe, and the age of the Kadzi Formation. - South African Journal of Geology 90: 107-119.

Rauhut, O. W. M. 2003. The interrelationships and evolution of basal theropod dinosaurs. - Special Papers in Palaeontology 69: 1-213.

Rauhut, O. W. M. 2005. Post-cranial remains of 'coelurosaurs' (Dinosauria, Theropoda) from the Late Jurassic of Tanzania. - Geological Magazine 142 (1): 97-107.

Reck, H. 1925. Grabungen auf fossile Wirbeltiere in Deutsch-Ostafrika. - Geologische Charakterbilder 31: 1-36.

Reck, H. 1931. Die deutschostafrikanischen Flugsaurier. - Centralblatt für Mineralogie, Geologie und Paläontologie, Abteilung B 1931: 321-336.

Reeves, C. V., Sahu, B. K. \& de Wit, M. 2002. A re-examination of the paleo-position of Africa's eastern neighbours in Gondwana. Journal of African Earth Sciences 34: 101-108.

Remes, K. 2006. Revision of the Tendaguru sauropod Tornieria africana (Fraas) and its relevance for sauropod paleobiogeography. Journal of Vertebrate Paleontology 26 (3): 651-669.

Remes, K. 2007. A second Gondwanan diplodocid dinosaur from the Upper Jurassic Tendaguru Beds of Tanzania, East Africa. - Palaeontology 50 (3): 653-667.

Romer, R. L. 2001. Isotopically heterogeneous initial $\mathrm{Pb}$ and continuous ${ }^{222} \mathrm{Rn}$ loss in fossils: The U-Pb systematics of Brachiosaurus brancai. - Geochimica et Cosmochimica Acta 65 (22): 4201-4213.

Russell, D., Béland, P. \& McIntosh, J. S. 1980. Paleoecology of the dinosaurs of Tendaguru (Tanzania). - Mémoires de la Société Géologique de France, Nouvelle Série 139: 169-175.

Salman, G. \& Abdula, I. 1995. Development of the Mozambique and Ruvuma sedimentary basins, offshore Mozambique. - Sedimentary Geology 96: 7-41.

Sames, B. 2005. Taxonomie, Biostratigraphie, Biogeographie und Paläoökologie von kalkigen Mikrofossilien (Ostracoda und Charophyta) der Tendaguruschichten (Oberjura/Unterkreide) am Tendaguru Hill, Tansania. - Sitzungsberichte der Gesellschaft Naturforschender Freunde zu Berlin, Neue Folge 44: 13-23.

Sames, B. 2008. Application of Ostracoda and Charophyta from the Late Jurassic to Early Cretaceous Tendaguru Formation at Tendaguru, Tanzania (East Africa) - Biostratigraphy, palaeobiogeography and palaeoecology. - Palaeogeography, Palaeoclimatology, Palaeoecology 264 (3-4): 213-229.

Schandelmeier, H., Bremer, F. \& Holl, H.-G. 2004. Kinematic evolution of the Morondava rift basin of SW Madagascar - from wrench tectonics to normal extension. - Journal of African Earth Sciences 38: 321-330.

Schlüter, T. 1997. Geology of East Africa. Borntraeger, Berlin and Stuttgart.

Schrank, E. 1999. Palynology of the dinosaur beds of Tendaguru (Tanzania) - Preliminary results. - Mitteilungen aus dem Museum für Naturkunde Berlin, Geowissenschaftliche Reihe 2: 171-183.

Schrank, E. 2004. A gymnosperm pollen not a dinoflagellate: a new combination for Mendicodinium? quadratum and description of a new pollen species from the Jurassic of Tanzania. - Review of Palaeobotany and Palynology 131: 301-309.

Schrank, E. 2005. Dinoflagellate cysts and associated aquatic palynomorphs from the Tendaguru Beds (Upper Jurassic - Lower Cretaceous) of southeast Tanzania. - Palynology 29: 49-85.

Schuchert, C. 1918. Age of the Morrison and East African Tendaguru formations. - Bulletin of the Geological Society of America 29: $245-280$. 
Schuchert, C. 1934. The Upper Jurassic age of the Tendaguru dinosaur beds. - American Journal of Science 27: 463-466.

Schudack, M. E. 1999. Charophytes from the Middle Dinosaur Member of the Tendaguru Formation (Upper Jurassic of Tanzania). Mitteilungen aus dem Museum für Naturkunde Berlin, Geowissenschaftliche Reihe 2: 201-205.

Schudack, M. E. \& Schudack, U. 2002. Ostracods from the Middle Dinosaur Member of the Tendaguru Formation (Upper Jurassic of Tanzania). - Neues Jahrbuch für Geologie und Paläontologie, Monatshefte 2002 (6): 321-336.

Scrutton, R. A. 1978. Davie Fracture Zone and the movement of Madagascar. - Earth and Planetary Science Letters 39: 84-88.

Scrutton, R. A., Heptonstall, W. \& Peacock, J. 1981. Constraints on the motion of Madagascar with respect to Africa. - Marine Geology 43: $1-20$.

Sieverts-Doreck, H. 1939. Jura- und Kreide-Crinoideen aus DeutschOstafrika. Mit einer Übersicht über jurassische Crinoideen aus Afrika und Madagaskar. - Palaeontographica, Supplement VII, 2. Reihe, Teil 3, Lieferung 3: 217-231.

Simpson, G. G. 1926. The age of the Morrison Formation. - American Journal of Science 12: 198-216.

Simpson, G. G. 1928. Mesozoic mammalia. XI. Brancatherulum tendagurense Dietrich. - American Journal of Science 15: 303-308

Spath, L. F. 1928-1933. Revision of the Jurassic cephalopod fauna of Kachh (Cutch). - Memoirs of the Geological Survey of India, Palaeontologica Indica, New Series, 9, Memoir 2, Part 2-6: 73-945.

Staff, H. von 1914. Beiträge zur Geomorphologie und Tektonik Deutsch-Ostafrikas. - I. Die geologisch-tektonischen Verhältnisse und die Entstehung der Oberflächenformen im südlichen Küstengebiete von Deutsch-Ostafrika. II. Einige tektonisch-morphologische Probleme Äquatorial-Afrikas von allgemeiner Bedeutung. - Archiv für Biontologie 3 (3): 73-226.

Stockey, R. A. 1978. Reproductive biology of Cerro Cuadro fossil conifers: Ontogeny and reproductive strategies in Araucaria mirabilis (Spegazzini) Windhausen. - Palaeontographica, Abteilung B 166: 1-15.

Stockey, R. A. 1982. The Araucariaceae: An evolutionary Perspective. - Review of Palaeobotany and Palynology 37: 133-154.
Süss, H. \& Schultka, S. 2001. First record of Glyptostroboxylon from the Upper Jurassic of Tendaguru, Tanzania. - Botanical Journal of the Linnean Society 135: 421-429.

Süss, H. \& Schultka, S. 2006. Koniferenhölzer (Fusite) aus dem Oberjura vom Tendaguru (Tansania, Ostafrika). - Palaeontographica, Abteilung B 275 (4-6): 133-165.

Teale, E. O. 1934. Provisional map of Tanganyika with explanatory notes. - Bulletin Geological Survey Department Tanganyika Territory 6: $1-32$.

Unwin, D. \& Heinrich, W.-D. 1999. On a pterosaur jaw remain from the Late Jurassic of Tendaguru, East Africa. - Mitteilungen aus dem Museum für Naturkunde Berlin, Geowissenschaftliche Reihe $2: 121-134$.

Vail, P. R., Mitchum, R. M. Jr. \& Thompson, S. III. 1977. Seismic stratigraphy and global changes of sea level, part four: global cycles of relative changes of sea level. - American Association of Petroleum Geologists Memoir 26: 83-96.

Veeken, P. C. \& Titov, K. V. 1996. Gravity modelling along a seismic line across the Mandawa basin, southeastern Tanzania. - Journal of African Earth Sciences 22 (2): 207-217.

Wade, F. B. 1937. A stratigraphical classification and table of Tanganyika Territory. - Department of Lands and Mines, Tanganyika Territory, Geological Division, Bulletin 9: 1-62.

Weissermel, W. 1900. Mesozoische und känozoische Korallen aus Deutsch-Ostafrika. In Bornhardt, W. (ed.). Zur Oberflächengestaltung und Geologie Deutsch-Ostafrikas. Deutsch-Ostafrika 7. Dietrich Reimer, Berlin: pp. 578-595.

Wild, R. 1991. Die Ostafrika-Reise von Eberhard Fraas und die Erforschung der Dinosaurier-Fundstelle Tendaguru. - Stuttgarter Beiträge zur Naturkunde, Serie C 30: 71-76.

Wopfner, H. 1992. Riftphasen und deren Einfluß auf das Öl und GasPotential tansanischer Karroo-Becken. - Zentralbatt für Geologie und Paläontologie 1991: 2703-2712.

Zils, W., Werner, C., Moritz, A. \& Saanane, C. 1995. Tendaguru, the most famous dinosaur locality of Africa. Review, survey and future prospects. - Documenta naturae 97: 1-41.

Zwierzycki, J. 1914. Die Cephalopodenfauna der Tendaguru-Schichten in Deutsch-Ostafrika. - Archiv für Biontologie 3 (4): 7-96. 